\title{
The Role of Informal Protected Areas in Maintaining Biodiversity in the Western Ghats of India
}

\author{
$\underline{\text { Shonil A. Bhagwat }}^{1}, \underline{\text { Cheppudira G. Kushalappa }}^{2}, \underline{\text { Paul H. Williams }}^{1}$, and Nick D. Brown ${ }^{3}$
}

\begin{abstract}
Although it is widely believed that an important function of protected areas is to conserve species that are unable to survive elsewhere, there are very few empirical studies in which a comparison is made between biodiversity of protected areas and that of the cultivated landscape surrounding them. We examined the diversity of trees, birds, and macrofungi at 58 sites in three land-use types in a tree-covered landscape in Kodagu district in the Western Ghats of India. Ten forest reserve sites in the formal protected area, and 25 sacred groves and 23 coffee plantations in the neighboring cultivated landscape were sampled. A total of 215 tree, 86 bird, and 163 macrofungus species were recorded. The forest reserve had a large number of trees that were restricted in their distribution, and the sacred groves had a large number of macrofungi. We observed that deciduous trees and non-forest-dwelling birds increased, and evergreen trees and forest-dwelling birds decreased with increasing intensity of land management. We found that trees having non-timber uses and macrofungi useful to the local people, as well as those with medicinal properties, were abundant in sacred groves. We found no significant differences in the distribution of endemic and threatened birds across the three land-use types. Although endemic trees were more abundant in the forest reserve than in sacred groves, threatened trees were more abundant in sacred groves than in the forest reserve. We attribute the high diversity in sacred groves to the native tree cover in shade coffee plantations. We conclude that informal protected areas are as important as formal ones for biodiversity conservation in Kodagu. We recommend that a conservation strategy that recognizes informal protection traditions is essential for successful biodiversity conservation in regions where formal reserves are surrounded by a matrix of cultivated land.
\end{abstract}

Key Words: biodiversity conservation; endemic and threatened species; medicinal plants; non-timber forest products; protected areas; sacred groves; Western Ghats of India

\section{INTRODUCTION}

One potential objective in designating a protected area is to conserve elements of biodiversity that are unable to survive elsewhere (Kramer et al. 1997, Bruner et al. 2001). However, there is growing recognition that the landscape matrix surrounding protected areas also plays an important role in protecting many species (Halpin 1997, Hannah et al. 2002). It has been shown that the distribution patterns of many of the species that are currently of the greatest international conservation concern do not coincide with broader diversity patterns (Prendergast et al. 1993, Oliver and Beattie 1996, Lawton et al. 1998, Williams et al. 2000, Perfecto et al. 2003). They may not, therefore, be adequately protected in areas set aside for biodiversity conservation. Successful conservation management requires an understanding of species' distributions (Roy 2003), including which species are restricted to protected areas and which are adequately protected outside these areas. There are very few empirical studies where such a comparison is made (but see Fabricius et al. 2003, Velazquez et al.2003), nor where the effectiveness of protected areas is compared with the surrounding landscape matrix from a range of stakeholder viewpoints, including that of the local people (but see Fabricius and Burger 1997, Khan et al. 1997).

\footnotetext{
${ }^{1}$ Natural History Museum, London, ${ }^{2}$ University of Agricultural Sciences College of Forestry, ${ }^{3}$ University of Oxford
} 
In this paper, we examine the distribution of biodiversity in a protected area and in the adjoining cultivated landscape, including sacred groves and coffee plantations, in the Western Ghats of India. We measure biodiversity of three contrasting groups of organisms: trees, birds, and macrofungi. We ask: Where in the landscape are species useful to the local people? Where are endemic and threatened species distributed? We discuss implications for landscape-scale biodiversity conservation.

\section{METHODS}

\section{Study Area}

The Kodagu district of Karnataka State in the Western Ghats of India extends between 11 ${ }^{\circ} 56^{\prime}-$ $12^{\circ} 52^{\prime} \mathrm{N}$ and $75^{\circ} 22^{\prime}-76^{\circ} 11^{\prime} \mathrm{E}$ (Pascal and MeherHomji 1986) (Fig. 1). The formal network of protected areas (the forest reserve) in the region consists of three wildlife sanctuaries and one national park, which stretch continuously along the western and the southwestern boundaries of the district, occupying about $30 \%$ of the area (Fig. 2). Plantations of shade-grown coffee occupy much of the remaining landscape (about 60\%). Here, coffee bushes are grown beneath a high tree canopy to shade the plantations. Approximately $8 \%$ of the total area is occupied by treeless land uses, such as paddy cultivation. The study region has a high density of sacred groves-one grove in every 300 ha (Kushalappa and Bhagwat 2001). These groves range in size from a fraction of a hectare to a few tens of hectares (S.A.B. and C.G.K., personal observation), and are often surrounded by shadegrown coffee cultivation. Sacred groves occupy only about $2 \%$ of the study area (Fig. 2).

\section{Sampling Design}

We selected 58 sites in three land-use types-the forest reserve, sacred groves, and coffee plantations - in a $600-\mathrm{km}^{2}$ area in southwestern Kodagu (Table 1). We sampled trees, birds, and macrofungi at ten forest reserve sites, 25 sacred groves, and 23 coffee plantations in 1999 and 2000 . We selected sacred groves so that they were well distributed across the study area, and across the range of different patch sizes (min. 0.2 ha, max. 48.1 ha, mean 13.2 ha, median $7.35 \mathrm{ha}$ ), as well as different distances from the forest reserve $(\min .1 \mathrm{~km}, \max .8 .6 \mathrm{~km}$, mean $4.4 \mathrm{~km}$, median $4.55 \mathrm{~km}$ ) (Table 1). We ensured that sampling sites in coffee plantations and forest reserve sites were also well distributed across the study area (Fig. 2). The forest reserve is a relatively homogenous and unbroken stretch of forest. We sampled more sites in sacred groves and coffee plantations than in the forest reserve, in order to take into account the heterogeneity of the cultivated landscape. Our strategy was to sample, at random, a predetermined number of individuals (observations in the case of birds and macrofungi) at each site, rather than sampling equal areas (Condit et al. 1996, Bibby et al. 1998), in order to overcome the problem of variable sizes of sampling sites and differences in the biological and ecological characteristics of organisms in question. We identified trees and birds to species, and macrofungi to recognizable taxonomic units according to their morphological features (i.e., morphotypes, referred to as species hereafter).

At each site, we selected a baseline (between st and fn in Fig. 3) that often ran along a natural or humanmade linear landscape feature (e.g., cart track, path, fence, boundary, stream) across the extent of the area. In most cases, this landscape feature was $<1$ $\mathrm{m}$ wide and canopy covered, thus minimally disturbed by human activity. Although the starting point of transect was on the baseline, the rest of the transect was perpendicular to the baseline, away from it. Furthermore, our objective was to obtain a sample of biodiversity that represented all habitats within the site rather than the "best" one. Therefore, we assumed that the proximity of baseline to humanmade landscape features in our sampling design is acceptable.

Before visiting a sampling site (for tree sampling), we generated random numbers in multiples of five. The starting points of individual transects were in the same sequence as the random numbers (Fig. 3). For example, if the first random number was 100 , we placed transect No. 1 at $100 \mathrm{~m}$ from the starting point along the baseline on a randomly chosen side -left or right. After completing the sampling along the first transect, we placed the second transect at a distance equal to the second random number (e.g., $225 \mathrm{~m}$, Fig. 3) from the starting point. We continued laying transects until we had counted at least 1000 trees $\geq 1 \mathrm{~cm}$ diameter at breast height (dbh) in sacred groves and forest reserve sites, and 100 trees $\geq 10$ $\mathrm{cm}$ dbh in coffee plantations, where small stems are regularly cut back. We repeated the process at each 
Fig. 1. The study area, showing Kodagu District in Karnataka State, India; sampling sites were located in the southwestern part of the district, where the continuous forest reserve adjoins cultivated landscape consisting of coffee plantations, and sacred groves.

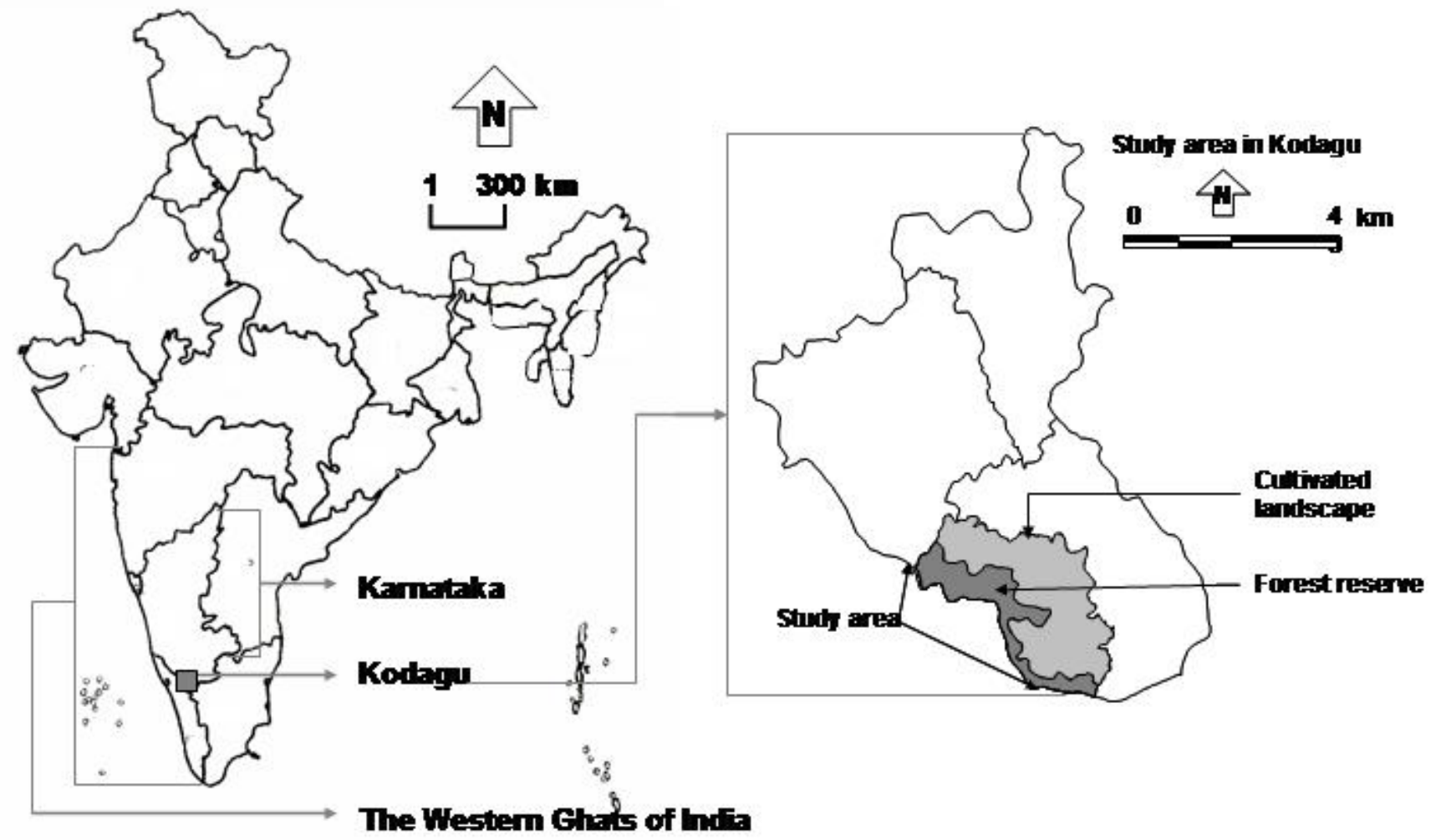

site. The lengths of transects varied between 20 and $100 \mathrm{~m}$ in accordance with patch sizes. We demarcated the baseline by painting blue arrows on adjacent trees. The direction of the baseline was usually along a cardinal direction. Therefore, we established vegetation transects exactly along a north-south line if the baseline was roughly eastwest, and vice versa. Seventy-five percent of our sampling sites were $<5$ ha in size. As a result, the framework of baseline and transects was spread across the entire area of most sampling sites, allowing us to obtain a sample that characterized the biodiversity of the whole site. We used the same framework of baseline and transects to sample birds and macrofungi.

We used the fixed radius point count method (Hutto et al. 1986) for bird sampling. The sampling team consisted of at least three people-two of them made observations and one recorded-so as to minimize errors in locating and counting birds. We carried out between five and fifteen 12-minute point counts at each site until we made at least 50 individual bird sightings (e.g., Thiollay 1994). At 
Fig. 2. Landscape map of the study area in Kodagu, Western Ghats of India, showing landscape composition and land uses studied; sampling sites are numbered according to the list in Table 1.

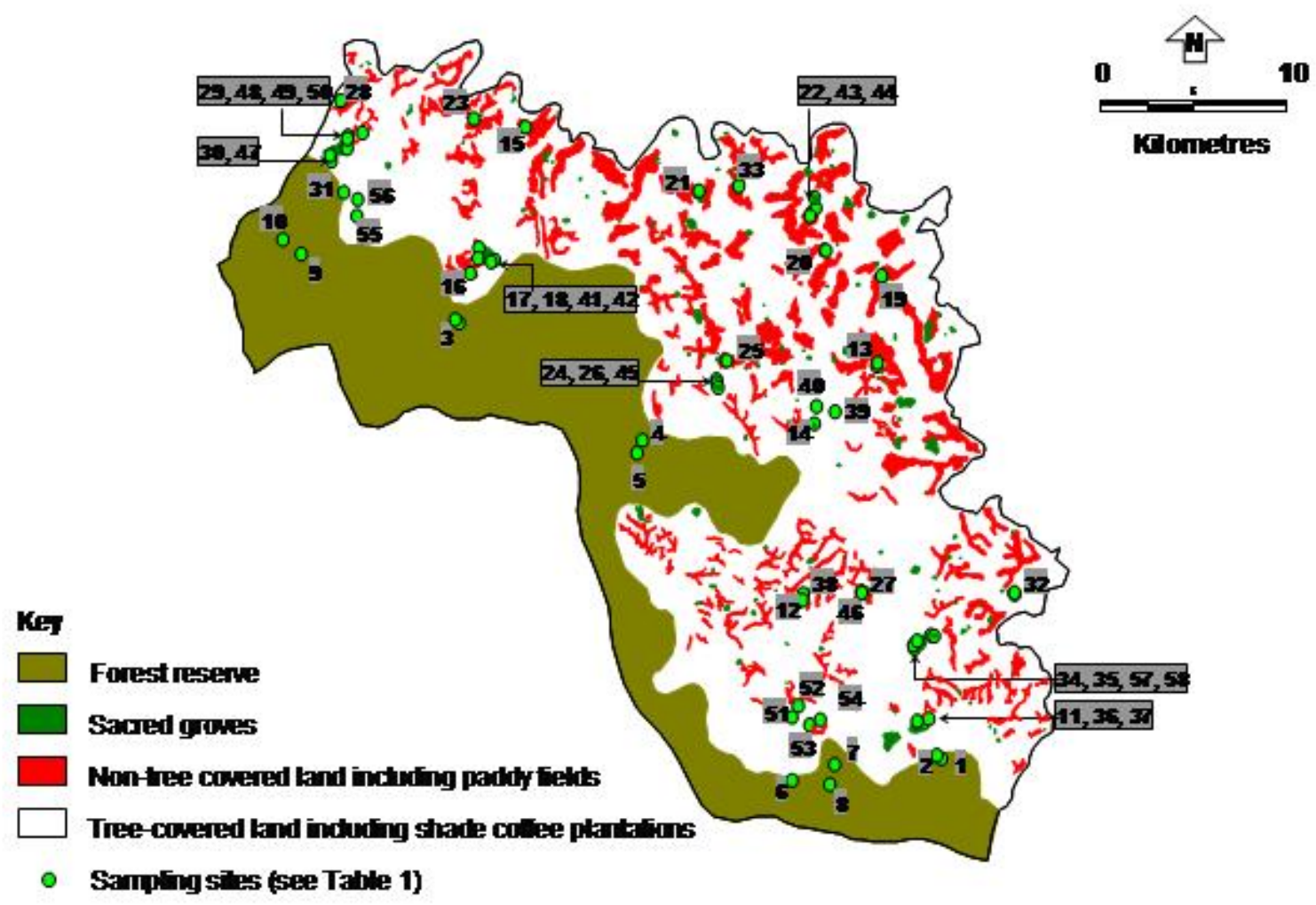

each point, all birds seen within a $25-\mathrm{m}$ radius through a pair of binoculars $(7 \times 50$ magnification $)$ were recorded by species. We normally began sampling at 7:00 a.m., and continued until the required number of observations was made.

We sampled macrofungal sporocarps in a $\geq 500-\mathrm{m}^{2}$ area along 5-m wide transects at each site (e.g., Senn-Irlet and Bieri 1999) on three different occasions during the monsoon season (JuneSeptember). A team of at least four people, two on either side of the central line, walked along the transects to ensure that all macrofungal sporocarps within the transect belt were recorded. We made at least 50 observations of macrofungal sporocarps. Some macrofungi produce single sporocarps, and others produce clusters. We recorded each cluster as one observation, regardless of the number of sporocarps in that cluster.

\section{Species Attributes}

The aim of our sampling was to measure the species diversity of trees, birds, and macrofungi. We did not "look" for species with specific attributes during 
Table 1. List of sampling sites in Kodagu, Western Ghats of India; the sites are identified by alphanumeric codes consisting of abbreviated village names and sampling reference numbers

\begin{tabular}{llll}
\hline \hline Sampling site & Altitude (m) & Size (ha) & D \\
\hline Forest reserve & & & \\
1. Bgrf31 & 870 & NA & 0 \\
2. Bgrfr32 & 870 & NA & 0 \\
3. Hgrf43 & 878 & NA & 0 \\
4. Kurfn49 & 927 & NA & 0 \\
5. Kurf550 & 923 & NA & 0 \\
6. Thrfc41 & 856 & NA & 0 \\
7. Thrfn03 & 833 & NA & 0 \\
8. Thrfs40 & 832 & NA & 0 \\
9. Torfe36 & 857 & NA & 0 \\
10. Torfw35 & 857 & NA & 0
\end{tabular}

Sacred groves

$\begin{array}{llll}\text { 11. Bgdsg30 } & 935 & 21.59 & 1.4 \\ \text { 12. Bkdsg26 } & 855 & 9.4 & 2.7 \\ \text { 13. Brdsg21 } & 812 & 1.3 & 5.3 \\ \text { 14. Brlsg01 } & 799 & 2.4 & 1.7 \\ \text { 15. Btdsg42 } & 879 & 12.1 & 4.8 \\ \text { 16. Hgdsg18 } & 917 & 2.4 & 1 \\ \text { 17. Hglsge16 } & 912 & 39.7 & 6.3 \\ \text { 18. Hglsgw15 } & 912 & 39.7 & 6.9 \\ \text { 19. Htdsg57 } & 822 & 8.9 & 8.2 \\ \text { 20. Icdsg53 } & 858 & 4 & 8 \\ \text { 21. Kbdsg51 } & 843 & 12.4 & 4.3 \\ \text { 22. Kdpaim54 } & 966 & 6.6 & 8.6 \\ \text { 23. Ktdsg44 } & 918 & 0.2 & 5.1 \\ \text { 24. Kudsg45 } & 860 & 3.7 & 1.9\end{array}$


25. Kuhdsg 48

26. Kulsg47

27. Pdlsg27

28. Pldsg 13

29. Pllsge 08

30. Pllsgw11

31. Topaij39

32. Tslsg58

33. Vbdsg 52

34. Wndsg24

35. Wnlsg22

\section{Coffee Plantations}

36. $\operatorname{Bg} \operatorname{cofd} 33$

37. Bgcofs 34

38. Bkcofc29

39. Brcofj02

40. Brcofn20

41. Hgcofa19

42. Hgcofu 17

43. Kdcof155

44. Kdcofs56

45. Kucofp46

45. Pdcofc 28

47. Plcofc10

48. Plcofd12

49. Plcofh09

50. Plcofr 14

51. Thcofa04

52. Thcofb05
857

847

870

930

935

956

910

820

824

845

849

935

935

855

799

799

912

912

866

866

860

870

956

910

935

902

847

865

3.2

2.8

2.2

4.9

2.5

1.4

4.7

1.6

6.4

5.7

4.4

4.3

$18.8 \quad 4.3$

NA $\quad 1.3$

NA $\quad 1.4$

NA $\quad 2.9$

NA $\quad 2.7$

NA 2.3

NA $\quad 1.2$

NA $\quad 1.5$

NA $\quad 8.3$

NA $\quad 8.5$

NA 2.1

NA $\quad 4.7$

NA $\quad 3.4$

NA $\quad 1.2$

NA $\quad 1.5$

NA 2.1

$\begin{array}{ll}\mathrm{NA} & 1.8\end{array}$

NA $\quad 1.7$ 


\begin{tabular}{llll}
\hline 53. Thcofg06 & 836 & NA & 8.8 \\
54. Thcofs07 & 836 & NA & 8 \\
55. Tocofc38 & 910 & NA & 8 \\
56. Tocofj37 & 910 & NA & 7 \\
57. Wncofd25 & 845 & NA & 4.5 \\
58. Wncof123 & 849 & NA & 4.1 \\
\hline
\end{tabular}

sampling, however, we categorized species according to their attributes when analyzing the data.

We classified trees into evergreen and deciduous categories, based on the published information (Pascal 1988, Keshavamoorthy and Yoganarasimhan 1989). We determined habitat preferences of bird species by prior knowledge or personal field observations, or based on species accounts in the field guides by Ali (1996) and Grimmett et al. (1998). We classified macrofungi according to their habitat preferences into two groups, namely, those fruiting on litter and those fruiting on wood, based on the information from the available literature (e. g., Jordan 1995) supplemented by field observations.

We determined the proportion of species endemic to the Western Ghats in different land-use types in this study, based on the Atlas of Endemics prepared by Ramesh and Pascal (1997). We also classified trees as non-threatened and threatened species based on the International Union for Conservation of Nature and Natural Resources (IUCN) threat categories (IUCN 2004) and examined their occurrence in different land-use types.

We classified species either as useful (for their nontimber product and medicinal value) or not useful to local people, and examined in which part of the landscape useful species persisted best. We consulted the Wealth of India (Council for Scientific and Industrial Research (CSIR) 1989) database for information on the usefulness of species, and a medicinal plants database prepared by Foundation for Revitalization of Local Health Traditions (FRLHT) to categorize species according to those with known medicinal properties and those without (FRLHT 1999).

\section{Statistical Analyses}

Although we sampled a predetermined number of individuals (for trees) or observations (for birds and macrofungi) at each site (see above), the numbers of sites sampled in the three land-use types were different (ten forest reserve sites, 25 sacred groves, and 23 coffee plantations). Therefore, we calculated the expected distribution of species by adjusting the species number to the sample size in the respective land-use type. Species that were found only in a single type were referred to as "restricted," those shared by any two of the three types as "shared," and those found in all three types as "widespread.' To compare the composition of restricted, shared, and widespread species, we used $\chi^{2}$ test.

To measure pairwise similarity in species composition of the three land-use types, we used Jaccard's Similarity Index, $S_{j}=j /(a+b-j)$, where " $\mathrm{j}$ " is the number of species found in both land-use types, "a" is the number of species in the first landuse type, and "b" is the number of species in the second land-use type (Magurran 1988).

To compare habitat preferences of species across the three land-use types, we used the Kruskal-Wallis analysis of variance (ANOVA) by ranks (StatSoft 1984-2003).

To compare the occurrence of endemic and threatened species, and useful and medicinal species across the three land-use types, we used the Kruskal-Wallis test (SPSS 1989-1999). 
Fig. 3. A schematic diagram of a representative sampling site in Kodagu, Western Ghats, India: a base line runs across the patch and the framework of transects is placed at random points along the baseline, on a randomly chosen side.

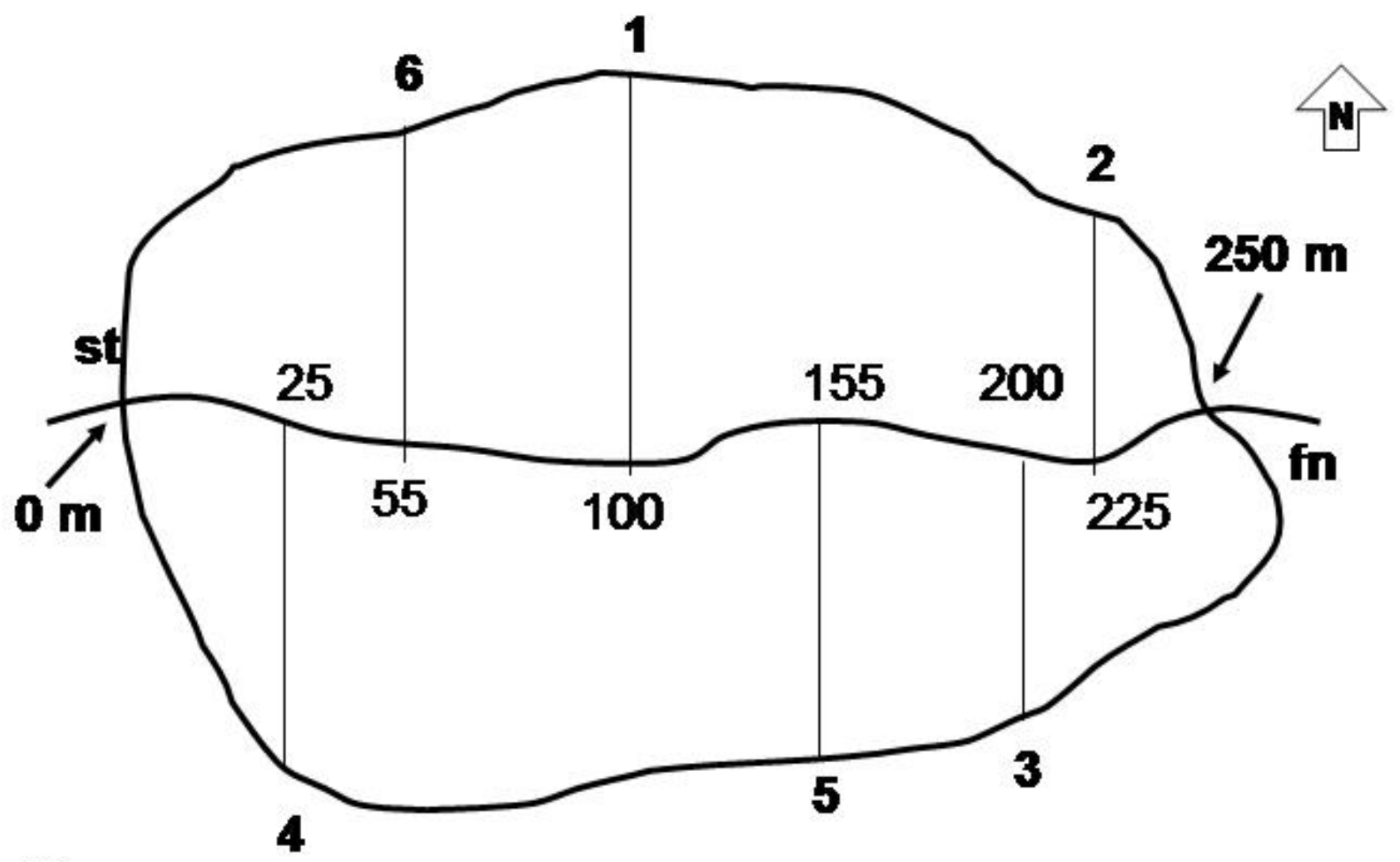

Key:

st, fn - start and finish of the base line

$25, \ldots 225$ - distance of random point from starting point $(\mathrm{m})$

$1, \ldots 6$

- transect numbers in sequence of measurement

\section{RESULTS}

\section{Distribution of Species}

We recorded a total of 215 tree species, 86 bird species, and 163 macrofungus species in the forest reserve, sacred groves, and coffee plantations. Their distribution in the three land-use types is shown in Fig. 4. The forest reserve and sacred groves were $58 \%$ similar, the forest reserve and coffee plantations $52 \%$ similar, and sacred groves and coffee plantations $69 \%$ similar in their tree species composition according to Jaccard's Similarity Index. These figures were $50 \%, 47 \%$, and $69 \%$, respectively, for birds; and $52 \%, 61 \%$, and $49 \%$, respectively, for macrofungi. The observed number of restricted tree species was higher than expected in the forest reserve, but lower in the sacred groves $\left(\chi^{2}\right.$ test, $\chi^{2}=6.992, \mathrm{df}=2, p$-value $\left.<0.05\right)$. Coffee plantations had nearly the same numbers of observed and expected tree species. The observed numbers of restricted bird species were not significantly different to the expected numbers $\left(\chi^{2}\right.$ test, $\chi^{2}=2.631$, df $=2, p$-value $\left.=0.0977\right)$ in any of 
Fig. 4. Numbers of restricted and shared species of a) trees, b) birds, and c) macrofungi in Kodagu, Western Ghats of India.

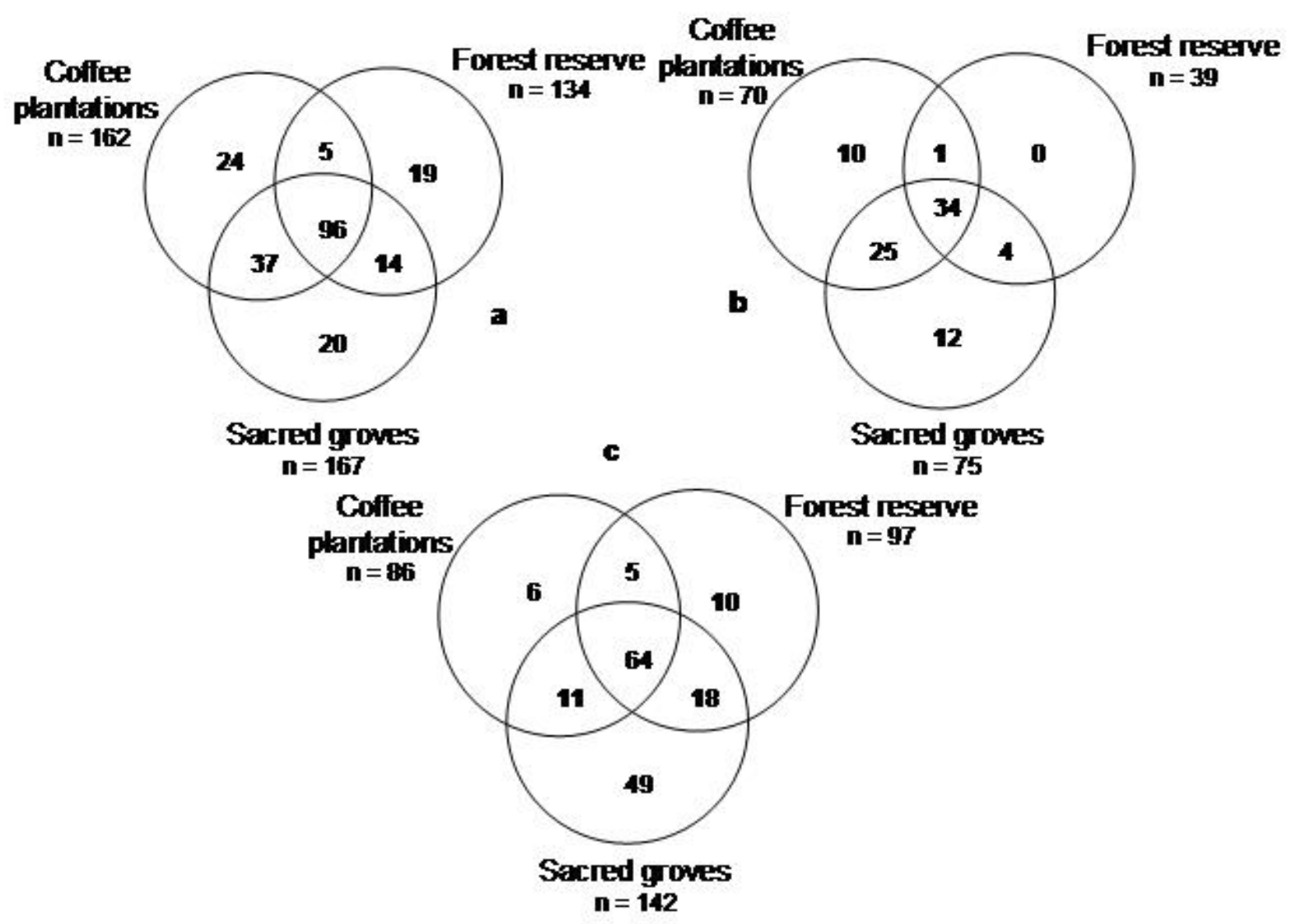

the three land-use types. The distribution of macrofungal species between the three land-use types was significantly different from expected $\left(\chi^{2}\right.$ test, $\chi^{2}=26.262, \mathrm{df}=2, p$-value $\left.<0.0001\right)$ because of the high numbers found in sacred groves.

\section{Species Attributes}

\section{Trees}

The proportion of evergreen tree species declined and that of deciduous tree species increased with increasing human intervention in land management (Kruskal-Wallis ANOVA by ranks, $\mathrm{H}=20.884$, df $=2, \mathrm{~N}=58, p$-value < 0.001) (Fig. 5a).

Sixty-three percent of tree species in the Western Ghats forests are reported to be endemic (Pascal and Pelissier 1996). Endemic trees were significantly more frequent in the forest reserve (Kruskal-Wallis test, $\chi^{2}=12.754, \mathrm{df}=2, p$-value $\left.<0.005\right)$, and nonendemic trees were significantly more frequent in coffee plantations (Kruskal-Wallis test, $\chi^{2}=8.306$, $\mathrm{df}=2, p$-value $=0.016)($ Table 2$)$. Threatened trees 
Fig. 5. Habitat preferences of a) trees, b) birds, and c) macrofungi in Kodagu, Western Ghats of India; Reserve $=$ forest reserve, Sacred $=$ sacred groves, Coffee $=$ coffee plantations. Note: error bars indicate 95 confidence limits.
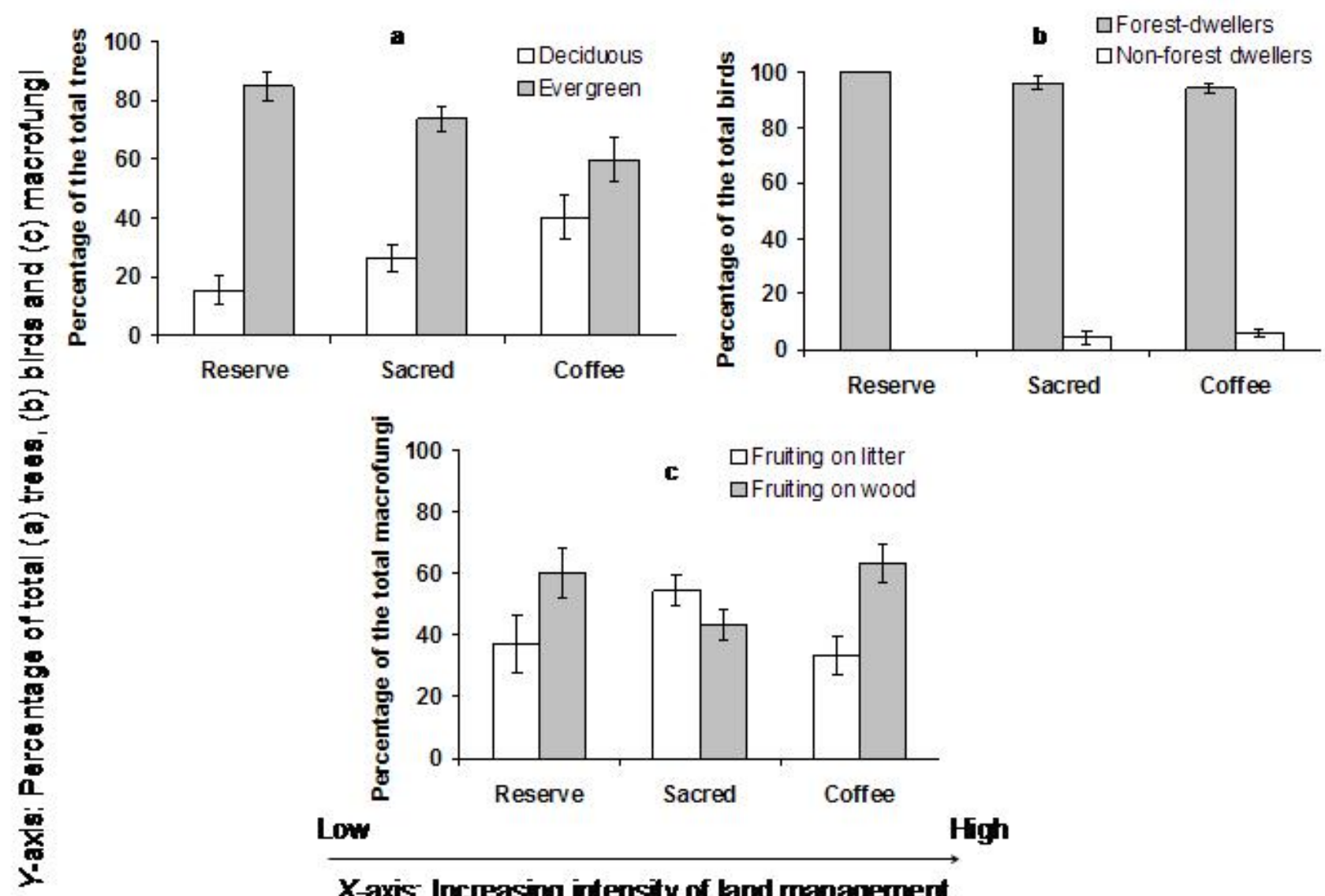

$X$-axis: Increasing intensity of band management

were significantly more frequent in sacred groves, and non-threatened ones were significantly less frequent (Kruskal-Wallis test, $\chi^{2}=11.465, \mathrm{df}=2$, $p$-value $=0.003$ ) compared with the forest reserve and coffee plantations (Table 2).

A total of $70 \%$ of species in Kodagu region yield useful non-timber forest products. The useful trees were significantly more frequent in coffee plantations (Kruskal-Wallis test, $\chi^{2}=7.553, \mathrm{df}=2$, $p$-value $<0.05$ ), and those that had no known use were significantly more frequent in the forest reserve (Kruskal-Wallis test, $\chi^{2}=7.224, \mathrm{df}=2, p$ value $<0.05)$. Trees with medicinal properties were significantly more frequent in coffee plantations (Kruskal-Wallis test, $\chi^{2}=6.992, \mathrm{df}=2, p$-value < $0.05)$ compared with the forest reserve and sacred groves.

\section{Birds}

Almost $80 \%$ of bird species ( 68 out of 86 ) in Kodagu prefer tree-covered to open habitats. Coffee 
Table 2. The distribution of endemic, threatened, useful, and medicinal trees in Kodagu, Western Ghats of India

\begin{tabular}{llll}
\hline \hline Attribute & $\begin{array}{l}\text { Forest reserve } \\
\text { No. of Species }\end{array}$ & $\begin{array}{l}\text { Sacred groves } \\
\text { No. of Species }\end{array}$ & $\begin{array}{l}\text { Coffee plantations } \\
\text { No. of Species }\end{array}$ \\
\hline Endemicity & & 47 & 39 \\
Endemic & 50 & 120 & 123 \\
Non-endemic & 84 & 32 & 27 \\
Threat status & & 135 & 135 \\
Threatened & 26 & & 118 \\
Non-threatened & 108 & 112 & 44 \\
Use value & & 55 & 48 \\
Useful & 83 & & 114 \\
No known use & 51 & 42 & \\
Medicinal value & & 125 & \\
Medicinal & 33 & & \\
Non-medicinal & 101 & & \\
\hline
\end{tabular}

plantations, with the most open canopies, had the highest proportion of non-forest dwellers, and the forest reserve, with the most closed canopy, had no non-forest-dwelling birds. The proportion of forestdwelling bird species decreased with the intensity of land management, and that of non-forest dwellers increased (Kruskal-Wallis ANOVA by ranks, $\mathrm{H}=$ 16.544, $\mathrm{df}=2, \mathrm{~N}=58, p$-value $<0.001)$ (Fig. 5b).

There was no significant difference in the distribution of endemic birds (Kruskal-Wallis test, $\chi^{2}=2.631, \mathrm{df}=2, p$-value $\left.=0.268\right)$. Very few birds in the region are threatened; their numbers were not sufficient to analyze the differences in their occurrence across the land-use types (Table 3 ).

\section{Macrofungi}

Although a large majority of sporocarps belonged to macrofungi fruiting on litter and those fruiting on wood, there were small proportions that belonged to either coprophilous macrofungi (growing on cattle dung, e.g., Coprinus sp.) or entomopathogenic macrofungi (parasitic on insects, e.g., Cordyceps sp.). The proportional distributions of sporocarps of macrofungi fruiting on litter and on wood are shown in Fig. 5c; the proportions of sporocarps belonging to coprophilous and entomopathogenic macrofungi were negligible $(1.8 \%, 2.1 \%$, and $3.8 \%$ in the forest reserve, sacred groves, and coffee plantations, respectively), and are not shown. Macrofungal species fruiting on litter were significantly more frequent in sacred groves, and those of macrofungal species fruiting on wood were significantly less frequent compared with the forest reserve and coffee plantations (Kruskal-Wallis ANOVA by ranks, $\mathrm{H}=19.601$, $\mathrm{df}=2, \mathrm{~N}=58, p$-value $<0.001)$, suggesting that the gradient of land management intensity does not have an effect on habitat preference of macrofungi.

Macrofungi such as some Agaricus spp., and some from the family Tricholomataceae, are reported to be edible, and a few others, such as Ganoderma spp. and Phellinus spp., are used locally for medicine. The edible (Kruskal-Wallis test, $\chi^{2}=12.437$, df $=$ $2, p$-value $<0.005)$ and medicinal (Kruskal-Wallis 
Table 3. The distribution of endemic and threatened birds in Kodagu, Western Ghats of India

\begin{tabular}{llll}
\hline \hline Attribute & $\begin{array}{l}\text { Forest reserve } \\
\text { No. of Species }\end{array}$ & $\begin{array}{l}\text { Sacred groves } \\
\text { No. of Species }\end{array}$ & $\begin{array}{l}\text { Coffee plantations } \\
\text { No. of Species }\end{array}$ \\
\hline Endemicity & & & 13 \\
Endemic & 12 & 14 & 57 \\
Non-endemic & 27 & 61 & 2 \\
Threat status & & & 68 \\
Threatened & 1 & 2 & \\
Non-threatened & 38 & 73 & \\
\hline
\end{tabular}

test, $\chi^{2}=19.077, \mathrm{df}=2, p$-value $\left.<0.0001\right)$ macrofungi were significantly more frequent in sacred groves than in the forest reserve and coffee plantations (Table 4.

\section{DISCUSSION}

\section{Distribution of Biodiversity in the Landscape}

Tree and bird species compositions of sacred groves and coffee plantations were most similar, and those of forest reserve and coffee plantations most dissimilar. This suggests that absence of human activity may be important in different species assemblages in the two parts of the landscape. We also found that intensity of land management influenced occurrence of evergreen and deciduous trees, and forest-dwelling and non-forest-dwelling birds in our sampling sites. The patterns of distribution of macrofungal species were different. The macrofungal assemblages in forest reserves and coffee plantations were most similar, and those of sacred groves and coffee plantations most dissimilar, suggesting the possibility that sacred groves shelter a distinctive assemblage. The distribution of macrofungal species across the three land-use types was significantly different from expected because of high numbers found in sacred groves, possibly because of a greater microhabitat heterogeneity that sacred groves provide in the landscape.

\section{Distribution of endemic and threatened species}

The forest reserve in Kodagu is important for conservation of endemic species. We found that many evergreen tree species, endemic to the Western Ghats, are restricted to the forest reserve (Table 5). The endemics are believed to be vulnerable to extinction (Bierregaard et al. 1997) because of their narrow distributions. These are also possibly habitat-specialist species that benefit from less disturbed, uninterrupted forest habitat within the reserve. The level of endemism in birds of the Western Ghats is low compared with trees (World Conservation Monitoring Centre (WCMC) 1992): $16 \%$ of the birds in the study area are endemic, in contrast to $63 \%$ of trees. We found no significant differences in the distribution of endemic birds between the forest reserve and the cultivated landscape. The ability of habitat-specialist birds to move freely, in contrast to trees, may be a factor that allows them to use both formally and informally protected parts of the landscape.

We found that sacred groves in Kodagu are important for protecting threatened trees, birds, and a distinctive macrofungal flora (cf. Jaffre et al. 1998). They shelter assemblages of species of conservation importance. We found that tree species such as Actinodaphne lawsonii, Hopea ponga, Madhuca neriifolia, and Syzygium zeylanicum that are listed as threatened (FRLHT 1999, IUCN 2004), were restricted to sacred groves. Other threatened species such as Michelia champaca and endemic species such as Pittosporum dasycaulon are found 
Table 4. The distribution of macrofungal sporocarps with and without utility value to the local people of Kodagu, Western Ghats of India

\begin{tabular}{llll}
\hline \hline Attribute & $\begin{array}{l}\text { Forest reserve } \\
\text { No. of species }\end{array}$ & $\begin{array}{l}\text { Sacred groves } \\
\text { No. of species }\end{array}$ & $\begin{array}{l}\text { Coffee plantations } \\
\text { No. of species }\end{array}$ \\
\hline Utility value & & 16 & 13 \\
Edible & 13 & 126 & 73 \\
Non-edible & 84 & & 15 \\
Medicinal value & & 22 & 71 \\
Medicinal & 17 & 120 & \\
Non-medicinal & 80 & &
\end{tabular}

in sacred groves and coffee plantations, but not in the forest reserve. Between $17 \%$ and $90 \%$ of stems of the threatened and endemic species were between 1 and $10 \mathrm{~cm} \mathrm{dbh}$, suggesting that these species are able to regenerate in sacred groves. As these species cannot regenerate in coffee plantations, where all small individuals are regularly cut back, their future survival will require propagation as shade trees to maintain tree cover in the landscape. The bird species such as the Loten's sunbird (Nectarinia lotenia), an endemic, and the Nilgiri Flycatcher (Eumyias albicaudata), an endemic and threatened bird, are restricted to sacred groves and coffee plantations. Forty-nine out of 163 species of macrofungi are restricted to sacred groves, possibly as a result of the high habitat heterogeneity of sacred groves.

\section{Distribution of useful species}

The cultivated landscape with its plantations and sacred groves is of direct value to the local people. We found that the useful and medicinal trees are more abundant in the cultivated landscape than in the formally protected one. This can be ascribed to the selective use of certain species by local people and their maintenance through traditional knowledge of their uses (cf. Colding and Folke 1997, 2001). Boraiah et al. (2003) have also found that the sacred groves of Kodagu have a greater number of medicinal plant species than the forest reserve. It is likely that the proximity of sacred groves to human settlements has resulted in a greater familiarity of the local people with the plant wealth of sacred groves. This may mean that people have been more likely to "discover" medicinal values of plants within sacred groves, and to select them for domestication. For example, Cinnamomum macrocarpum is a tree that yields valuable NTFPs, such as the bark, used in spices. Other parts of the tree are also used in medicinal preparations, and the tree is listed by FRLHT (1999) as a priority species for conservation. Although the tree is widespread over the entire landscape, its selective use and retention is reflected in its size-class distributions (Fig. 6). Large size classes are found only in coffee plantations, presumably because they are retained by the landowners for periodic harvesting of the bark, which fetches a good market price. The species regenerates better in sacred groves than in the forest reserve, therefore, possibly maintaining healthy populations in the cultivated landscape.

We also found that useful and medicinal macrofungi are more frequently encountered in the cultivated landscape. Tropical forests are known to provide a large range of non-wood products that are important for the local economy (Myers 1988). In a study in the northeast of Peru (Pinedo-Vasquez et al. 1990), $60 \%$ of species were found to be useful to the local people for food, construction, craft, medicine, etc. Macrofungi are also one of the important nontimber forest products in the local economy in many tropical regions (Hartshorn 1995). In the Western Ghats, as elsewhere in the tropics, rural livelihoods depend on the non-wood products found in the neighboring forest. The cultivated landscape in 
Table 5. Evergreen tree species restricted to the forest reserve in Kodagu; those marked with an asterisk are species that are also endemic to the Western Ghats of India

\section{Evergreen tree species and their families}

* Aglaia elaeagnoidea (Meliaceae)

Agrostistachys meeboldii (Euphorbiaceae)

* Baccaurea courtallensis (Euphorbiaceae)

* Blachia denudata (Euphorbiaceae)

* Diospyros pruriens (Ebenaceae)

* Drypetes oblongifolia (Euphorbiaceae)

* Elaeocarpus munronii (Elaeocarpaceae)

* Garcinia indica (Clusiaceae)

Garcinia pictoria (Clusiaceae)

* Heritiera papilio (Sterculiaceae)
* Humboldtia brunonis (Fabaceae - Caesalpinioideae)

* Litsea glabrata (Lauraceae)

Litsea insignis (Lauraceae)

* Mallotus stenanthus (Euphorbiaceae)

Memecylon wightii (Melastomataceae)

Mitrephora heyneana (Annonaceae)

Polyalthia coffeoides (Annonaceae)

* Schefflera capitata (Araliaceae)

Syzygium lanceolatum (Myrtaceae)
Kodagu caters to this need, possibly reducing resource-use pressure on the forest reserve.

\section{Role of Tree Cover in Maintaining Biodiversity}

Although the species composition of the cultivated landscape in Kodagu has been highly influenced by the intensity of land management, more than $75 \%$ of this landscape is still under tree cover. This is because planters have retained many native trees to provide shade for coffee plantations. The treecovered landscape may be an important factor in maintaining forest-dwelling biodiversity in sacred groves (Bhagwat et al. in press).

The tree cover in the landscape possibly reduces the severity of microclimatic changes, such as higher temperatures, increased wind speed, lower humidity, and lower soil moisture, introduced by forest fragmentation (Geiger 1965, Kapos et al. 1997, Freidenberg 1998). As a result, there may be less edge-related disturbance, and more habitat available for forest-dwelling species and less for non-forest-dwelling species. Consequently, sacred groves may support more forest-interior species than would be the case in a landscape where forest patches are surrounded by arable land alone. The tree cover also possibly facilitates movements of organisms such as birds through the landscape matrix surrounding sacred groves, which these organisms can use for foraging and other resources as well. As a result, coffee plantations may be harboring transitory individuals that are not able to reside within plantations alone. The plantations may also be harboring more individuals of forestdwelling species than would be the case in a purely arable landscape matrix. As a consequence, coffee plantations in Kodagu may be harboring a greater number species than would be the case in an arable matrix.

Andrén (1994) found that, in landscapes with less than $30 \%$ cover of suitable habitat, habitat loss was a good predictor of diversity. However, in landscapes with higher habitat cover, habitat loss was not a good predictor of diversity in birds and mammals. O'Neill et al. (1988) in their spatial analysis have also observed that, above $30 \%$, suitable habitat becomes almost continuous across the landscape. Many organisms are able to move easily across such landscape. For highly mobile organisms, this critical cover threshold will be much lower than for relatively less mobile ones. As a 
Fig. 6. Cinnamomum macrocarpum, which is medicinal and also yields other valuable non-timber forest products, regenerates better in sacred groves $(n=19)$; the trees in the largest size classes are retained in coffee plantations $(n=18)$, but are absent from the forest reserve $(n=5)$ in Kodagu, Western Ghats of India. Note: error bars indicate $95 \%$ confidence limits.
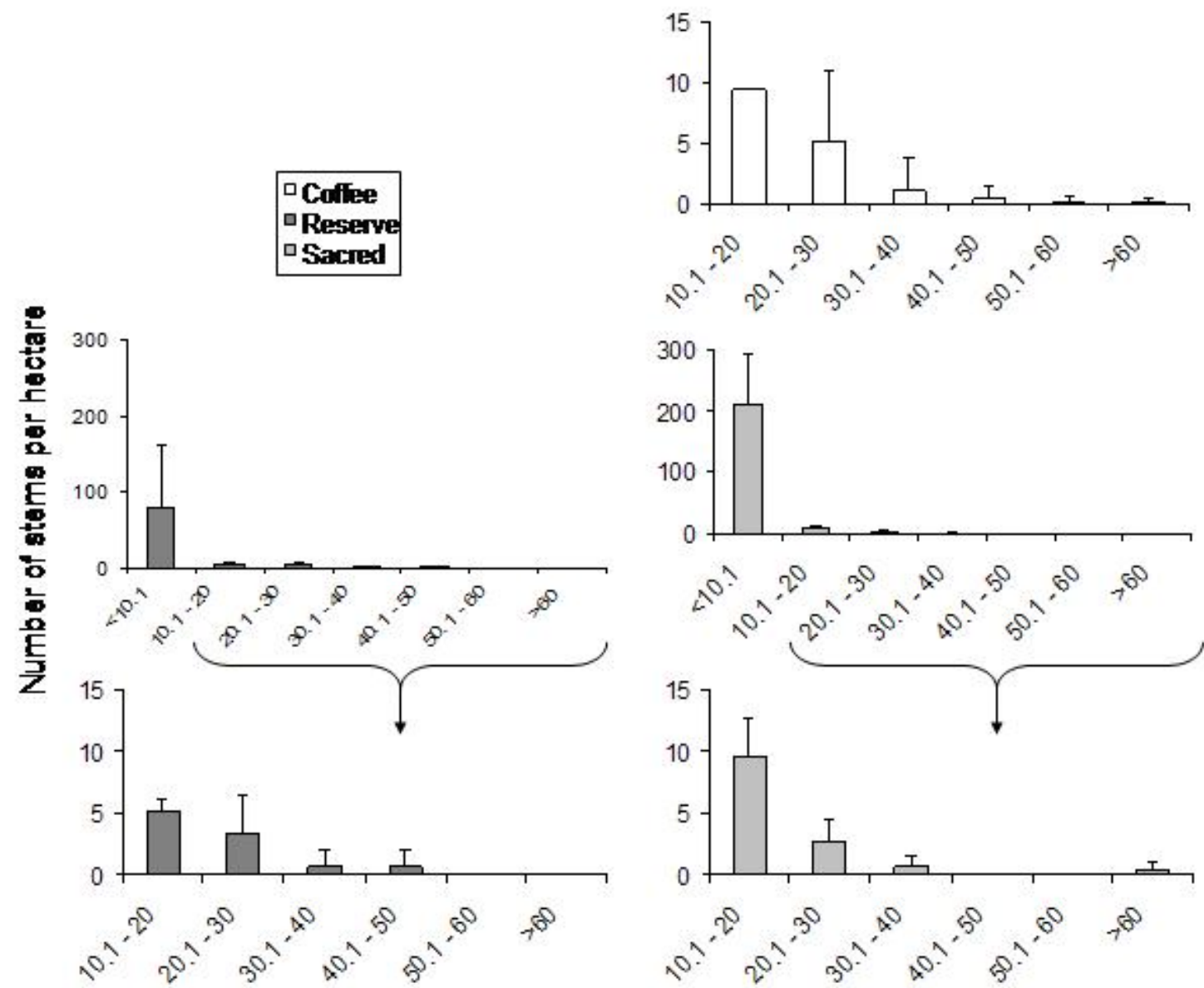

Dbh classes (cm)

consequence of the relatively continuous landscape, the sacred groves in Kodagu may not actually be perceived as "patches" by the organisms using them. Therefore, the diversity of trees, birds, and macrofungi was relatively similar between the forest reserve, sacred groves, and coffee plantations, despite the variation in intensity of land management. To maintain the integrity of the Kodagu landscape, active plantation of native trees in coffee estates, biodiversity-friendly coffee cultivation, and creation of a market for organically grown coffee may be essential (Bhagwat et al. in press).

\section{Role of Informal Protected Areas in Conservation}

Although the tree cover in the cultivated landscape in Kodagu has been valuable for maintaining landscape-scale diversity, the conservation ethic of the local people of protecting forest patches has also 
played a significant role in providing suitable habitat for many forest-dwelling organisms. Traditional societies are known to base their resource management on different rationales than most Western nature management and conservation systems (Colding and Folke 2001). Sacred groves in the Western Ghats are believed to have existed for more than two millennia (Gadgil 1992, Chandran 1997), and are present in high densities in Kodagu (Kushalappa and Bhagwat 2001). Every village in Kodagu is known to have at least one, and up to 12, sacred groves (S.A.B. and C.G.K., personal observation). In many biodiversity-rich developing countries, informal institutions are neglected, and formal protection has been the major approach to protecting biodiversity (Colding and Folke 2001). Despite the widespread presence of sacred groves, they are not included in the regional conservation design in the Western Ghats.

Brown (2003) has suggested that the conservation management institutions in tropical regions should take into account the complexity of ecosystems in question. Although the forest reserve in Kodagu provides a continuous habitat to species with large home ranges and those with special habitat requirements, the presence of sacred groves in the cultivated landscape ensures landscape-scale heterogeneity of habitats beneficial to many other organisms. The sacred groves also contribute to the protection of ecosystems, such as lowland marshes and swamps, outside the formal protected area. Furthermore, sacred groves and coffee plantations in Kodagu shelter species of trees and macrofungi useful to the local peoples' livelihoods. These species are in low numbers in the adjacent forest reserve (e.g., Fig. 6), possibly because of the lack of human activity in maintaining the populations of useful species. Although anthropogenic disturbance can be important in developing diversity and resilience in ecological systems, the formal conservation institutions often seek to minimize this disturbance (Brown 2003). In Kodagu, the forest reserve alone will not be adequate to maintain biodiversity; sacred groves are important.

There is now growing consensus among conservation planners that forest patches such as sacred groves are likely to be the key to maintaining biodiversity in the increasingly urbanized world. In recent years, the conservation community has also come to realize that the long-term survival of biodiversity depends on the effectiveness with which such forest remnants can be managed.
Colding and Folke (2001) have proposed that conservation planners should devote careful consideration to already existing, local, informal institutions, and involve local people in planning. Berkes (2004) has argued that there has been a shift in ecology and applied ecology toward a systems view of the environment, a perspective that sees humans as part of the ecosystem. In Kodagu, biodiversity conservation will benefit from such an approach.

\section{Prescribed Conservation Measures}

\section{Official recognition of sacred grove traditions}

In modern-day India, although many traditions are eroding, a large number of sacred groves are still conserved through taboos and religious beliefs. Chandrakanth et al. (1990) suggest that such sacred acts should be recognized by the government. The fifth IUCN World Parks Congress in Durban (September 2003) acknowledged that local communities all over the world have conserved many sites through traditional means, but their importance has been neglected in formal conservation circles. The Congress recommended that the importance of community-conserved areas should be recognized (Kothari 2003). Although official recognition at the national and the international level will be important for land-tenure security of sacred groves in Kodagu, participation of local people in their management will also be essential (e.g., Colding and Folke 2001).

\section{A system of rewards for effective protection}

Many sacred groves in Kodagu are still well protected. Maintaining sacred groves is considered important to the local people (e.g., Chandrakanth and Nagaraja 1997) because of the cultural and spiritual appeal that such landscapes have (Posey 1998, McNeely 2003). However, some sacred groves have come under threat because of encroachment by neighboring coffee plantation owners (Bonn 2000). It has been suggested that a system of rewards may work for the effective protection of sacred groves (e.g., Chandrashekara and Sankar 1998). Sacred groves are important sources of non-timber forest products. Local people depend on them for fuelwood, green fodder, medicinal herbs, and other livelihood necessities. An organized system for harvesting, utilizing, and marketing such products may be necessary. The 
profit generated from such enterprises can be shared equitably between the government and the local community. Such initiatives also need to be complemented by appropriate legislation that can provide the necessary land-tenure security and resource-use rights to the local communities.

\section{Toward joint planning and management}

Khare et al. (2000) have found that foresters and villagers in some parts of India view joint forest management (JFM) very differently: many forestry department officials see JFM primarily as a means of ensuring the rehabilitation of degraded forests, but village communities view it as a solution to the growing shortage of biomass, a means of obtaining the daily requirements of forest products, and a way to increase income. It is necessary to bring foresters and villagers together to initiate a dialogue and to reach agreement on the objectives of JFM of sacred groves. In recent years, the government departments, non-government organizations, and local communities in Kodagu have undertaken coordinated efforts to develop and implement conservation strategies for sacred groves. The regional forest departments, in consultation with local people and organizations, will need to explore ways to manage sacred groves for maintaining biodiversity in Kodagu.

We suggest that informal community-managed areas are equally as important to conservation as formal protected areas (e.g., Margules and Pressey 2000, Sinclair et al. 2000, Bhagwat et al. 2001, Brooks et al. 2001, Wilshusen et al. 2002). In Kodagu, the integrity of the cultivated landscape should be maintained through the initiative and involvement of the local people. We recommend that a conservation strategy that recognizes the importance of informal protection approaches is essential for successful biodiversity conservation.

Responses to this article can be read online at: http://www.ecologyandsociety.org/vol10/iss1/art8/responses/

\section{Acknowledgments:}

This project was funded by a research grant to Oxford Forestry Institute, UK, from the Conservation, Food and Health Foundation, Boston, Massachussetts, USA. S.A.B.'s doctoral research at the Department of Plant Sciences was supported by the Rhodes Trust, the Radhakrishnan Memorial Bequest, Linacre College, and the University of Oxford Graduate Studies Committee. We thank Md. Ashfaq, K.T. Boraiah, H.R. Kamal Kumar, K.M. Nanaya, C. Shivanad, and B.S. Tambat for their assistance during the fieldwork in Kodagu. The co-supervision of S. Jennings and P. Savill during S.A.B.'s doctoral research is gratefully acknowledged. The discussion with R. Whittaker and M. Swaine was very useful. The comments from Dick Vane-Wright and two anonymous reviewers were very valuable in improving the manuscript. $S$. A.B. is grateful to the Biodiversity World project (www.bdworld.org) for supporting his current postdoctoral position at the Natural History Museum. The cost of publishing this article was paidfor by the Resilience Alliance.

\section{LITERATURE CITED}

Ali, S. 1996. The book of Indian birds. Oxford University Press, Mumbai, India.

Andrén, H. 1994. Effects of habitat fragmentation on birds and mammals in landscapes with different proportions of suitable habitat: a review. Oikos 71:355-366.

Balmford,A., and A. Long. 1994. Avian endemism and forest loss. Nature 372:623-624.

Berkes, F. 2004. Rethinking community-based conservation. Conservation Biology 18(3):621630.

Bhagwat,S.A., C. G. Kushalappa, P. H. Williams, and N. D. Brown. 2005. A landscape approach to biodiversity conservation of sacred groves in the Western Ghats of India. Conservation Biology in press.

Bhagwat, S., N. D. Brown, T. Evans, S. B. Jennings, and P. S. Savill. 2001. Parks and factors in their success (Letters to Science). Science 293:1045-1047.

Bibby, C., M. Jones, and S. Marsden. 1998. Bird surveys. Royal Society for the Protection of Birds, Sandy, Bedfordshire, UK. 
Bierregaard, R. O., W. F. Laurance, J. W. Sites, A. J. Lynam, R. K. Didham, M. Andersen, C. Gascon, M. D. Tocher, A. P. Smith, V. M. Viana, T. E. Lovejoy, C. E. Sieving, E. A. Kramer, C. Restrepo, and C. Moritz. 1997. Key priorities for the study of fragmented tropical ecosystem. Pages 515-525 in W. F. Laurance, and R. O. Bierregaard, editors. Tropical forest remnants: ecology, management and conservation of fragmented communities. The University of Chicago Press, Chicago, Illinois, USA.

Boraiah, K. T., R. Vasudeva, S. A. Bhagwat, and C. G. Kushalappa. 2003. Do informally managed sacred groves have higher richness and regeneration of medicinal plants than state-managed reserve forests? Current Science 84:804-808.

Brooks, T., A. Balmford, N. Burgess, J. Fjeldsa, L. A. Hansen, J. Moore, C. Rahbek, and P. Williams. 2001. Toward a blueprint for conservation in Africa. Bioscience 51:613-624.

Brown, K. 2003. Integrating conservation and development: a case of institutional misfit. Frontiers in Ecology and the Environment 1(9):479-487.

Bonn, E. 2000. An economic framework to land extensification. Pages 79-88 in P. S. Ramakrishnan, U. M. Chandrashekara, C. Elouard, C. Z. Guilmoto, R. K. Maikhuri, K. S. Rao, S. Sankar, and K. G. Saxena, editors. Mountain biodiversity, land use dynamics, and traditional knowledge. Man and the Biosphere Programme, Oxford and IBH Publishing, New Delhi, India.

Bruner, A. G., R. E. Gullison, R. E. Rice, and G. A. B. da Fonseca. 2001. Effectiveness of parks in protecting tropical biodiversity. Science 291:125128.

Chandrakanth, M. G., J. K. Gilless, V. Gowramma, and M. G. Nagaraja 1990. Temple forests in India's forest development. Agroforestry Systems 11:199-211.

Chandrakanth, M. G., and M. G. Nagaraja. 1997. Existence value of Kodagu sacred groves: implications for policy. Pages $217-224$ in A. Agarwal, editor. The challenge of the balance: environmental economics in India. Centre for Science and Environment, New Delhi, India.
Chandran, M.D.S. 1997. On the ecological history of the Western Ghats. Current Science 73:146-155.

Chandrashekara, U. M., and S. Sankar. 1998. Structure and functions of sacred groves: case studies in Kerala. Pages $323-335$ in P. S. Ramakrishnan, K. G. Saxena, and U. M. Chandrashekara, editors. Conserving the sacred for biodiversity management. Oxford and IBH Publishing, New Delhi, India.

Colding, J., and C. Folke. 1997. The relations among threatened species, their protection, and taboos. Conservation Ecology 1(1):6 (Online.) URL: http://www.consecol.org/vol1/iss1/art6/

Colding, J., and C. Folke. 2001. Social taboos: "invisible" systems of local resource management and biological conservation. Ecological Applications 11(2):584-600.

Condit, R., S. P. Hubbell, J. V. Lafrankie, R. Sukumar, N. Manokaran, R. B. Foster, and P. S. Ashton. 1996. Species-area and species-individual relationships for tropical trees: a comparison of three 50-ha plots. Journal of Ecology 84:549-562.

Council for Scientific and Industrial Research (CSIR). 1989. The useful plants of India. Council for Industrial and Scientific Research, New Delhi, India.

Fabricius, C., and M. Burger. 1997. Comparison between a nature reserve and adjacent communal land in xeric succulent thicket: an indigenous plant user's perspective. South African Journal of Science 93:259-262.

Fabricius, C., M. Burger, and P. A. R. Hockey. 2003. Comparing biodiversity between protected areas and adjacent rangeland in xeric succulent thicket, South Africa: arthropods and reptiles. Journal of Applied Ecology 40:392-403.

Freidenberg, L. K. 1998. Physical effects of habitat fragmentation. Pages 66-79 in P. L. Fielder, and P. M. Kareiva, editors. Conservation biology for the coming decade. Chapman and Hall, New York, New York, USA.

Foundation for Revitalisation of Local Health Traditions (FRLHT). 1999. Priority list of medicinal plants in South India. Foundation for Revitalisation of Local Health Traditions, 
Bangalore, India.

Gadgil, M. 1992. Conserving biodiversity as if people matter: a case study from India. Ambio 21:266-270.

Geiger, R. 1965. The climate near the ground. Harvard University Press, Cambridge, Massachussetts, USA.

Grimmett, R., C. Inskipp, and T. Inskipp. 1998. Birds of the Indian Subcontinent. Christopher Helm A \& C Black, London, UK.

Halpin, P. N. 1997. Global climate change and natural-area protection: management responses and research directions. Ecological Applications 7:828843.

Hannah, L., G. F. Midgley, and D. Millar. 2002. Climate change-integrated conservation strategies. Global Ecology and Biogeography 11:485-495.

Hartshorn, G. S. 1995. Ecological basis for sustainable development in tropical forests. Annual Review of Ecology and Systematics 26:155-175.

Hutto, R. I., S. M. Pletschet, and P. Hendricks. 1986. A fixed-radius point count method for nonbreeding and breeding season use. Auk 103:593602.

International Union for Conservation of Nature and Natural Resources (IUCN). 2004. 2004 IUCN red list of threatened species. IUCN Species Survival Commission, Gland, Switzerland. (Online.) URL:http://www.redlist.org/

Jaffre, T., P. Bouchet, and J. M. Veillon. 1998. Threatened plants of New Caledonia: is the system of protected areas adequate? Biodiversity and Conservation 7:109-135.

Jordan, M. 1995. The encyclopaedia of fungi of Britain and Europe. David \& Charles, London, UK.

Kapos, V., E. Wandelli, J. L. Camargo, and G. Ganade. 1997. Edge-related changes in environment and plant responses due to forest fragmentation in Central Amazonia. Pages 33-44 in W. F. Laurance and R.O. Bierregaard, editors. Tropical forest remnants: ecology, management and conservation of fragmented communities. The University of Chicago Press, Chicago, Illinois, USA.
Keshavamoorthy, K. R., and S. N. Yoganarasimhan. 1989. Flora of Coorg. Vimsat Publishers, Bangalore, India.

Khan, M. L., S. Menon, and K. S. Bawa. 1997. Effectiveness of the protected area network in biodiversity conservation: a case-study of Meghalaya state. Biodiversity and Conservation 6:853-868.

Khare, A., M. Sarin, N. C. Saxena, S. Palit, S. Bathla, F. Vania, and M. Satyanarayana. 2000. Joint forest management: policy, practice and prospects. World Wide Fund for Nature-India; International Institute for Environment and Development, New Delhi, India; London, UK.

Kothari, A. 2003. Recommendation 26: community conserved areas. WPC Recommendation $5.26, \mathrm{~V}^{\text {th }}$ IUCN World Parks Congress, Durban, South Africa. (Online.) URL:

http://www.iucn.org/themes/wcpa/wpc2003/pdfs/outputs/ recommendations/approved/english/html/r26.htm.

Kushalappa, C. G., and S. Bhagwat. 2001. Sacred groves: biodiversity, threats and conservation. Pages 21-29 in U. R. Shaankar, K. N. Ganeshaiah, and K. S. Bawa, editors. Forest genetic resources: status, threats, and conservation. Oxford and IBH, New Delhi, India.

Kramer, R., C. van Schaik, and J. Johnston. 1997. Last stand: protected areas and the defence of tropical biodiversity. Oxford University Press, New York, New York, USA.

Lawton, J. H., D. E. Bignell, B. Bolton, G. F. Bloemers, P. Eggleton, P. M. Hammond, M. Hodda, R. D. Holt, T. B. Larsen, N. A. Mawdsley, N. E. Stork, D. S. Srivastava, and A. D. Watt. 1998. Biodiversity inventories, indicator taxa and effects of habitat modification in tropical forest. Nature 391:72-76.

Magurran, A. E. 1988. Ecological diversity and its measurement. Chapman and Hall, London, UK.

Margules, C. R., and R. L. Pressey. 2000. Systematic conservation planning. Nature 405:243253.

McNeely, J. 2003. Recommendation 13: Cultural and spiritual values of protected areas. WPC 
Recommendation 5.13, $\mathrm{V}^{\text {th }}$ IUCN World Parks Congress, Durban, South Africa. (Online.) URL: http://www.iucn.org/themes/wcpa/wpc2003/pdfs/outputs/ recommendations/approved/english/html/r13.htm.

Myers, N. 1988. Tropical forests: much more than stocks of wood. Journal of Tropical Ecology 4:209_ 221.

Myers, N., R. A. Mittermeier, C. G. Mittermeier, G. A. B. da Fonseca, and J. Kent. 2000. Biodiversity hotspots for conservation priorities. Nature 403:853-858.

Oliver, I. O., and A. J. Beattie. 1996. Designing a cost-effective invertebrate survey: a test of methods for rapid assessment of biodiversity. Ecological Applications 6:594-607.

Olson, D. M., and E. Dinerstein. 1998. The global 200: a representation approach to conserving the earth's most biologically valuable ecoregions. Conservation Biology 12:502-515.

Olson, D. M., and E. Dinerstein. 2002. The Global 200: priority ecoregions for global conservation. Annals of the Missouri Botanical Garden 89:199224.

O'Neill R. V., B. T. Milne, M. G. Turner, and R. H. Gardner. 1988. Resource utilisation scales and landscape pattern. Landscape Ecology 2:63-69.

Pascal, J. P. 1988. Wet Evergreen forests of the Western Ghats of India: ecology, structure, floristic composition and succcession. Institut français de Pondichéry, Pondicherry, India.

Pascal, J. P., and V. M. Meher-Homji. 1986. Phytochorology of Kodagu (Coorg) district, Karnataka. Journal of Bombay Natural History Society 83:43-56.

Pascal, J. P., and R. Pelissier. 1996. Structure and floristic composition of a tropical evergreen forest in southern India. Journal of Tropical Ecology 12:191-214.

Perfecto, I., A. Mas, T. Dietsch, and J. Vandermeer. 2003. Conservation of biodiversity in coffee agroecosystems: a tri-taxa comparison in southern Mexico. Biodiversity and Conservation 12:1239-1252.
Pinedo-Vasquez, M., D. Zarin, P. Jipp, and J. Chota-Inuma. 1990. Use-values of tree species in a communal forest reserve in northeast Peru. Conservation Biology 4:405-416.

Posey, D. A. 1998. Cultural and spiritual values of biodiversity. IUCN, United Nations Environment Programme, Gland, Switzerland.

Prendergast, J. R., R. M. Quinn, J. H. Lawton, B. C. Eversham, and D. W. Gibbons. 1993. Rare species, the coincidence of diversity hotspots and conservation strategies. Nature 365:335-337.

Ramesh, B. R., and J. P. Pascal 1997. Atlas of endemics of the Western Ghats (India): distribution of tree species in the evergreen and semi-evergreen forests. Institut français de Pondichéry, Pondicherry, India.

Roy, P. S. 2003. Biodiversity conservationperspective from space. National Academy Science Letters-India 26:169-184.

Senn-Irlet, B., and G. Bieri. 1999. Sporocarp succession of soil-inhabiting macrofungi in an autochtonous subalpine Norway spruce forest of Switzerland. Forest Ecology and Management 124:169-175.

Sinclair, A. R. E., D. Ludwig, and C. W. Clark. 2000. Conservation in the real world. Science 289: 1875 .

SPSS. 1989-1999. SPSS for Windows Release 10.0.5. SPSS Inc., Chicago, Illinois, USA.

StatSoft. 1984-2003. Statistica 6.1. Statsoft Inc., Tulsa, Oklahoma, USA.

Thiollay, J.-M. 1994. The role of traditional agroforests in the conservation of rain forest bird diversity in Sumatra. Conservation Biology 9:335353.

Velazquez, A., G. Bocco, F. J. Romero, and A. P. Vega. 2003. A landscape perspective on biodiversity conservation-the case of central Mexico. Mountain Research and Development 23:240-246.

World Conservation Monitoring Centre (WCMC). 1992. Global biodiversity: status of the Earth's living resources. World Conservation Monitoring 
Centre, Chapman and Hall, London, UK.

Williams, P. H., N. D. Burgess, and C. Rahbek. 2000. Flagship species, ecological complementarity and conserving the diversity of mammals and birds in sub-Saharan Africa. Animal Conservation 3:249260.

Wilshusen, P. R., S. R. Brechin, C. L. Fortwangler, and P. C. West. 2002. Reinventing a square wheel: critique of a resurgent "protection paradigm"' in international biodiversity conservation. Society \& Natural Resources 15:17-40. 
APPENDIX 1. Checklist and distribution of tree species in three land-use types in the Kodagu district of Karnataka State in the Western Ghats of India (* indicates presence)

\begin{tabular}{|c|c|c|c|}
\hline Scientific name of species & Forest reserve & Sacred forests & Coffee plantations \\
\hline Acrocarpus fraxinifolius & * & $*$ & $*$ \\
\hline Acronychia pedunculata & & $*$ & $*$ \\
\hline Actinodaphne bourdillonii & $*$ & $*$ & $*$ \\
\hline Actinodaphne lawsonii & $*$ & & \\
\hline Actinodaphne malabarica & $*$ & $*$ & $*$ \\
\hline Aglaia anamallayana & $*$ & $*$ & \\
\hline Aglaia barberi & $*$ & & $*$ \\
\hline Aglaia elaeagnoidea & $*$ & & \\
\hline Aglaia jainii & $*$ & $*$ & $*$ \\
\hline Aglaia simplicifolia & $*$ & $*$ & \\
\hline Agrostistachys meeboldii & $*$ & & \\
\hline Albizzia amara & & $*$ & $*$ \\
\hline Albizzia chinensis & & & $*$ \\
\hline Albizzia lebbek & & & $*$ \\
\hline Alstonia scholaris & $*$ & $*$ & $*$ \\
\hline Antidesma menasu & $*$ & $*$ & $*$ \\
\hline Antiaris toxicaria & & $*$ & \\
\hline Aphananthe cuspidata & $*$ & $*$ & $*$ \\
\hline Aphanamixis polystachya & $*$ & $*$ & $*$ \\
\hline Apodytes beddomei & $*$ & $*$ & $*$ \\
\hline Aporosa lindleyana & & $*$ & $*$ \\
\hline Archidendron monadelphum & $*$ & $*$ & $*$ \\
\hline Ardisia solanacea & & $*$ & \\
\hline Areca catechu & & & $*$ \\
\hline Artocarpus heterophyllus & $*$ & $*$ & $*$ \\
\hline Artocarpus hirsuta & $*$ & $*$ & $*$ \\
\hline
\end{tabular}


Baccouria courtallensis

Beilschmiedia wightii

Bischofia javanica

Blachia denudata

Bombax ceiba

Bombax malabaricum

Bridelia retusa

Calophyllum polyanthum

Callicarpa tomentosa

Canthium dicoccum

Canarium strictum

Careya arborea

Carallia brachiata

Caryota urens

Cassia fistula

Cassine glauca

Casearia ovata

Casearia rubescens

Casearia wynadensis

Ceiba pentandra

Celtis philippensis

Celtis tetrandra

Chionanthus malabaricum

Chrysophyllum lanceolatum

Cinnamoтum macrocarpum

Cinnamomum sulphuratum

Citrus reticulata

Clausena dentata

Cleidion spiciflorum

*

*

*

$*$

*

*
$*$

$*$

$*$

$*$

$*$

$*$

$*$

*

$*$

*

$*$

$*$

$*$

*

$*$

$*$ 
Clerodendron viscosum

Coffea arabica

Cryptocarya bourdillonii

Chrysophylum lanceolatum

Cytheroxylon subserratum

Dalbergia latifolia

Dillenia pentagyna

Dimocarpus longan

Diospyros candolleana

Diospyros montana

Diospyros paniculata

Diospyros pruriens

Diospyros sp.

Diospyros sylvatica

Drypetes elata

Drypetes oblongifolia

Dysoxylum malabaricum

Elaeocarpus munronii

Elaeocarpus serratus

Elaeocarpus tuberculatus

Emblica officinalis

Erythrina indica

Euonymus indicus

Evodia lunu-ankenda

Excoecaria crenulata

Fragraea ceilanica

Ficus amplissima

Ficus asperima

Ficus beddomei
$*$

$*$

$*$

$*$

$*$

$*$

$*$

*

$*$

$*$
$*$

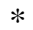

$*$

*

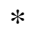

*

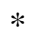

$*$

$*$

*

*

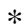

$*$

*

$*$

$*$

$*$

$*$

$*$

*

$*$ 
Ficus benghalensis

Ficus callosa

Ficus glomerata

Ficus hispida

Ficus microcarpa

Ficus mysorensis

Ficus nervosa

Ficus racemosa

Ficus sp.

Ficus tsjahela

Ficus virens

Flacourtia montana

Garcinia gummi-gutta

Garcinia indica

Garcinia morella

Garcinia pictorius

Glochidion bourdillonii

Glochidion malabaricum

Glyricidia maculata

Gmelina arborea

Grevillea robusta

Grewia tiliaefolia

Harpullia arborea

Heritiera papilio

Holigarna arnottiana

Holigarna beddomei

Holigarna grahamii

Holigarna nigra

Homalium travancoricum
*

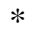

$*$

$*$

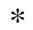

$*$

*

$*$

$*$

$*$

*

$*$

$*$

$*$

*

$*$

*

$*$

$*$

$*$

$*$

*

*

*

*

*

$*$

* 
Homalium zeylanicum

Hopea parviflora

Hopea ponga

Humboldtia brunonis

Hydnocarpus alpina

Hydnocarpus pentandra

Isonandra lanceolata

Knema attenuata

Kydia calycina

Lagerstroemia lanceolata

Lannea coromandelica

Laportea crenulata

Leea indica

Lepisanthes deficiens

Ligustrum perottetti

Litsea floribunda

Litsea glabrata

Litsea insignis

Litsea mysorensis

Litsea oleoides

Litsea stocksii

Lophopetalum wightianum

Macaranga peltata

Madhuca neriifolia

Mallotus philippensis

Mallotus stenanthes

Mangifera indica

Margaritaria indica

Mastixia arborea
$*$

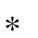

$*$

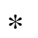

$*$

$*$

$*$

$*$

*

*

$*$

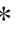

$*$

*

$*$

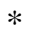

$*$

*

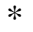

$*$

$*$

*

*

* 
Maytenus rothiana

Memecylon malabaricum

Memecylon talbotianum

Memecylon umbellatum

Memecylon wightii

Mesua ferrea

Michelia champaca

Microtropis wallichiana

Mimusops elengi

Mitrephora heyneana

Mitragyna tubulosa

Myristica dactyloides

Neolitsea zeylanica

Nothopegia beddomei

Nothapodytes foetida

Ochna lanceolata

Olea dioica

Oroxylum indicum

Otonephelium stipulaceum

Pajanelia rheedii

Palaquium ellipticum

Pavetta sp.

Persea macrantha

Pittosporum dasycaulon

Polyalthia coffeoides

Polyalthia fragrans

Pongamia pinnata

Premna tomentosa

Prunus ceilanica

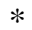

$*$

*

*

$*$

$*$

*

$*$

*

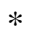

$*$

*

$*$
*

*

*

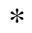

*

*
$*$

*

$*$

$*$

$*$

*

*

*

$*$

*

*

*

*

$*$

*

$*$

*

*

*

*

* 
Psidium guajava

Pterocarpus marsupium

Schefflera capitata

Schefflera micrantha

Schleichera oleosa

Schefflera sp.

Schefflera wallichiana

Scleropyrum pentandrum

Scolopia crenata

Spondias indica

Spondias pinnata

Stereospermum chelonioides

Sterculia guttata

Stereospermum personatum

Streblus asper

Strombosia ceylanica

Symplocos macrophylla

Symplocos racemosa

Syzygium cumini

Syzygium gardnerii

Syzygium hemisphericum

Syzygium heyneanum

Syzygium lanceolatum

Syzygium mundagam

Syzygium munronii

Syzygium phyllareoides

Syzygium rubicundum

Syzygium zeylanicum

Tabernaemontana heyniana
$*$
$*$

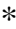

$*$

$*$

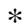

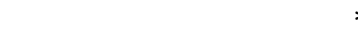

$*$

$*$

$*$

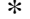

$*$

$*$

$*$

$*$

*

*

$*$

$*$

$*$ 
Terminalia bellarica

Toona ciliata

Trema orientalis

Trichilia connaroides

Turpinia malabarica

Unidentified

Vateria indica

Vepris bilocularis

Vernonia monosis

Viburnum punctatum

Villebrunea integrifolia

Vitex altissima

Xanthophyllum flavescens

Xanthoxylum rhetsa

Xeromphis spinosa
$*$

$*$

$*$

*

$*$
$*$

$*$

$*$

*

$*$

$*$

$*$

$*$

$*$

$*$
$*$

$*$

$*$

$*$

$*$ $*$ $*$

*

$*$

$*$

* 
APPENDIX 2. Checklist and distribution of bird species in three land-use types in Kodagu District, Karnataka State in the Western Ghats of India (* indicates presence)

\begin{tabular}{|c|c|c|c|c|}
\hline Common name & Scientific name & Forest reserve & Sacred forests & Coffee plantations \\
\hline Asian Brown Flycatcher & Muscicapa dauurica & & $*$ & \\
\hline Asian Fairy Bluebird & Irena puella & $*$ & $*$ & $*$ \\
\hline Asian Koel & Eudynamic scolopacea & & $*$ & $*$ \\
\hline Alexandrine Parakeet & Psittacula eupatria & & $*$ & \\
\hline Asian Paradise Flycatcher & Terpsiphone paradisi & & $*$ & $*$ \\
\hline Ashy Woodswallow & Artamus fuscus & & & $*$ \\
\hline Banded Bay Cuckoo & Cacomantis sonneratii & & $*$ & \\
\hline Black-crested Bulbul & Pycnonotus melanicterus & $*$ & $*$ & $*$ \\
\hline Brown-cheeked Fulvetta & Alcippe poioicephala & $*$ & $*$ & $*$ \\
\hline Black-hooded Oriole & Oriolus xanthornus & & & $*$ \\
\hline Black Bulbul & Hypsipetes leucocephalus & & $*$ & $*$ \\
\hline Black Drongo & Dicrurus macrocerus & $*$ & $*$ & $*$ \\
\hline Black Eagle & Ictinaetus malayensis & & & $*$ \\
\hline Black-naped Monarch & Hypothymis azurea & $*$ & $*$ & $*$ \\
\hline Black-rumped Flameback & Dinopium benghalense & & $*$ & $*$ \\
\hline Blue-capped Rock Thrush & Monticola cinclorhynchus & $*$ & & $*$ \\
\hline Black-shouldered Kite & Elanus caeruleus & & $*$ & \\
\hline Blue-winged Leafbird & Chloropsis cochinchinensis & & $*$ & $*$ \\
\hline Baya Weaver & Ploceus philippinus & & $*$ & $*$ \\
\hline Chestnut-bellied Nuthatch & Sitta castanea & & $*$ & $*$ \\
\hline Crimson-backed Sunbird & Nectarinia minima & $*$ & $*$ & $*$ \\
\hline Common Chiffchaff & Phylloscopus collybita & & $*$ & $*$ \\
\hline Crimson-fronted Barbet & Megalaima rubricapilla & $*$ & $*$ & $*$ \\
\hline Chestnut-headed Bee-eater & Merops leschenaulti & & $*$ & $*$ \\
\hline Common Flameback & Dinopium javanense & $*$ & $*$ & $*$ \\
\hline Common Iora & Aegithina tiphia & * & $*$ & $*$ \\
\hline
\end{tabular}




\begin{tabular}{|c|c|c|c|c|}
\hline Common Myna & Acridotheres tristis & & $*$ & * \\
\hline Common Tailorbird & Orthotomus sutoris & & & $*$ \\
\hline Common Woodshrike & Tephrodornis pondicerianus & & $*$ & $*$ \\
\hline Crested Serpant Eagle & Spilornis cheela & $*$ & $*$ & $*$ \\
\hline $\begin{array}{l}\text { Chestnut-shouldered } \\
\text { Petronia }\end{array}$ & Petronia xanthocollis & & $*$ & \\
\hline Chestnut-tailed Starling & Sturnus Malabaricus & & $*$ & $*$ \\
\hline Dark Fronted Babbler & Rhopocichla atriceps & $*$ & $*$ & \\
\hline Eurasian Golden Oriole & Oriolus oriolus & $*$ & $*$ & $*$ \\
\hline Emerald Dove & Chalcophaps indica & & $*$ & \\
\hline Green Bee-eater & Merops orientalis & & $*$ & $*$ \\
\hline $\begin{array}{l}\text { Grey-headed Canary } \\
\text { Flycatcher }\end{array}$ & Culicicapa ceylonensis & $*$ & $*$ & $*$ \\
\hline Gold-fronted Leafbird & Chloropsis aurifrons & & $*$ & $*$ \\
\hline Greater Coucal & Centropus sinensis & & $*$ & $*$ \\
\hline $\begin{array}{l}\text { Greater Racket-tailed } \\
\text { Drongo }\end{array}$ & Dicrurus paradiseus & $*$ & $*$ & * \\
\hline Greater Flameback & Chrysocolaptes lucidus & $*$ & $*$ & $*$ \\
\hline Hill Myna & Gracula religiosa & $*$ & $*$ & $*$ \\
\hline House Sparrow & Passer domesticus & & $*$ & \\
\hline House Crow & Corvus splendens & & $*$ & \\
\hline House Swift & Apus affinis & $*$ & $*$ & $*$ \\
\hline Heart-spotted Woodpecker & Hemicircus canente & & $*$ & $*$ \\
\hline Indian Scimitar Babbler & Pomatorhinus horsfieldii & $*$ & $*$ & $*$ \\
\hline Jungle Myna & Acridotheres fuscus & & $*$ & $*$ \\
\hline Jungle Prinia & Prinia sylvatica & $*$ & $*$ & $*$ \\
\hline Large-billed Crow & Corvus macrorhyncus & $*$ & $*$ & $*$ \\
\hline Loten's Sunbird & Nectarinia lotenia & & $*$ & $*$ \\
\hline Long-tailed Shrike & Lanius schach & & & $*$ \\
\hline Malabar Grey Hornbill & Ocyceros griseus & $*$ & $*$ & $*$ \\
\hline Mountain Imperial Pigeon & Ducula badia & $*$ & $*$ & $*$ \\
\hline
\end{tabular}




\begin{tabular}{|c|c|c|c|c|}
\hline Malabar Parakeet & Psittacula columboides & $*$ & $*$ & $*$ \\
\hline Malabar Trogon & Harpactes fasciatus & * & $*$ & \\
\hline Malabar Whistling Thrush & Myophonus horsfieldii & $*$ & $*$ & $*$ \\
\hline Nilgiri Flycatcher & Eumyias albicaudata & & $*$ & $*$ \\
\hline Nilgiri Wood Pigeon & Columba elphinstonii & * & $*$ & $*$ \\
\hline Orange-headed Thrush & Zoothera citrina & * & & \\
\hline Oriental Magpie Robin & Copsychus saularis & & $*$ & $*$ \\
\hline Oriental White-eye & Zosterops palpebrosus & & & $*$ \\
\hline Pale-billed flowerpecker & Dicaeum erythrorhyncus & $*$ & $*$ & * \\
\hline Plum-headed Parakeet & Psittacula cyanocephala & * & $*$ & $*$ \\
\hline Purple-rumped Sunbird & Nectarinia zeylonica & & $*$ & \\
\hline Puff-throated Babbler & Pellornium ruficeps & * & $*$ & * \\
\hline Purple Sunbird & Nectarinia asiatica & & $*$ & \\
\hline Rose-ringed Parakeet & Psittacula krameri & & & $*$ \\
\hline Red-vented Bulbul & Pycnonotus cafer & & & * \\
\hline Red-whiskered Bulbul & Pycnonotus jocosus & & $*$ & * \\
\hline Scarlet Minivet & Pericrocotus flammeus & $*$ & $*$ & * \\
\hline Shikra & Accipiter badius & $*$ & $*$ & $*$ \\
\hline Small Minivet & Pericrocotus cinnamomeus & & & $*$ \\
\hline Spotted Dove & Streptopelia chinensis & & $*$ & * \\
\hline Tickell's Blue Flycatcher & Cyornis tickelliae & $*$ & $*$ & * \\
\hline Velvet-fronted Nuthatch & Sitta frontalis & & $*$ & $*$ \\
\hline Vernal Hanging Parrot & Loriculus vernalis & & $*$ & * \\
\hline White-browed Fantail & Rhipidura auriola & & $*$ & \\
\hline White-bellied Treepie & Dendrocitta leucogastra & * & $*$ & $*$ \\
\hline White-bellied Woodpecker & Dryocopus javensis & * & $*$ & $*$ \\
\hline White-cheeked Barbet & Megalaima viridis & $*$ & $*$ & $*$ \\
\hline White-eyed Buzzard & Butastur Teesa & $*$ & $*$ & \\
\hline White-throated Kingfisher & Halcyon smyrnensis & & $*$ & $*$ \\
\hline
\end{tabular}




\begin{tabular}{llll} 
White-browed Wagtail & Motacilla maderaspatensis & $*$ & $*$ \\
Yellow-browed Bulbul & Iole indica & $*$ & $*$ \\
Yellow-footed Green Pigeon & Treron phoenicoptera & $*$ & $*$ \\
\hline
\end{tabular}


APPENDIX 3. Checklist and distribution of macrofungal morphotypes in three land-use types in Kodagu District, Karnataka State in the Western Ghats of India (* indicates presence; collection information and images of the macrofungal morphotypes can be found in the BRAHMS Database of Western Ghats Macrofungi)

\begin{tabular}{|c|c|c|c|}
\hline Name of morphotype & Forest reserve & Sacred forests & Coffee plantations \\
\hline Agaricus sp. (brown) & & $*$ & $*$ \\
\hline Agaricus sp. & $*$ & $*$ & $*$ \\
\hline Amanita sp. & & $*$ & \\
\hline $\begin{array}{l}\text { Ascomycetes (yellow-colored, ball-like } \\
\text { sporocarps) }\end{array}$ & $*$ & $*$ & $*$ \\
\hline Ascomycetes (elephant dung) & $*$ & $*$ & $*$ \\
\hline Ascomycetes (spoon) & & $*$ & \\
\hline Ascomycetes (thread) & & $*$ & \\
\hline Astraeus sp. & & $*$ & \\
\hline Auricularia sp. & $*$ & $*$ & $*$ \\
\hline Boletus sp. & & $*$ & $*$ \\
\hline Callocybe sp. & $*$ & $*$ & \\
\hline Unknown (Chili-red) & $*$ & & \\
\hline Clavaria sp. (brown) & & $*$ & \\
\hline Clavaria sp. & $*$ & $*$ & $*$ \\
\hline Clavaria sp. (orange) & $*$ & $*$ & $*$ \\
\hline Clavaria sp. (purple) & & $*$ & \\
\hline Clavaria sp. (Ramaria like) & $*$ & & \\
\hline Clavaria sp. (tree) & $*$ & $*$ & \\
\hline Clavaria sp. (white) & $*$ & $*$ & \\
\hline Clitocybe sp. & $*$ & $*$ & $*$ \\
\hline Collybia sp. (brown in color) & $*$ & $*$ & $*$ \\
\hline Collybia sp. (Hygrophorus like) & & $*$ & $*$ \\
\hline Collybia sp. (unknown) & $*$ & $*$ & $*$ \\
\hline
\end{tabular}




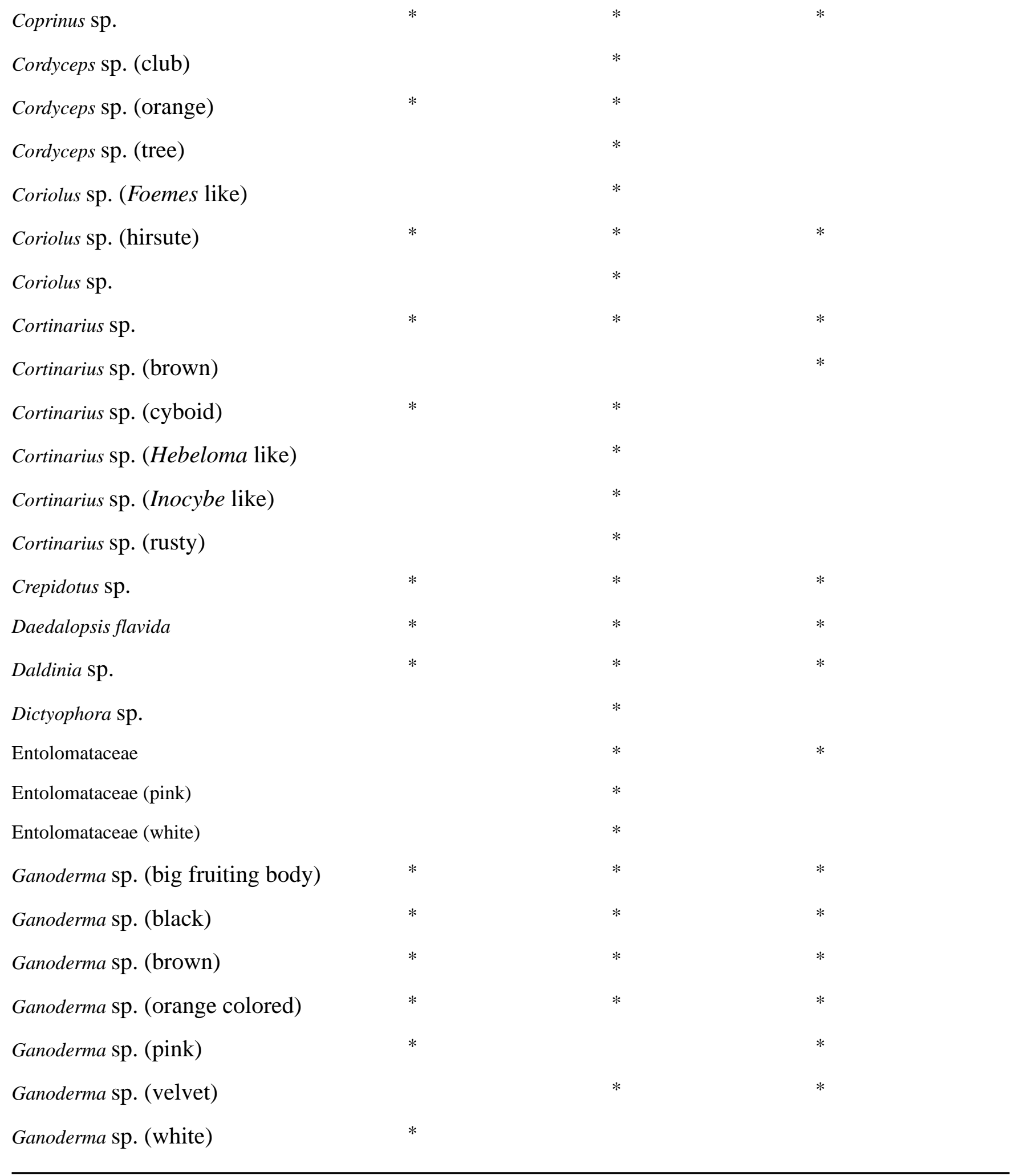




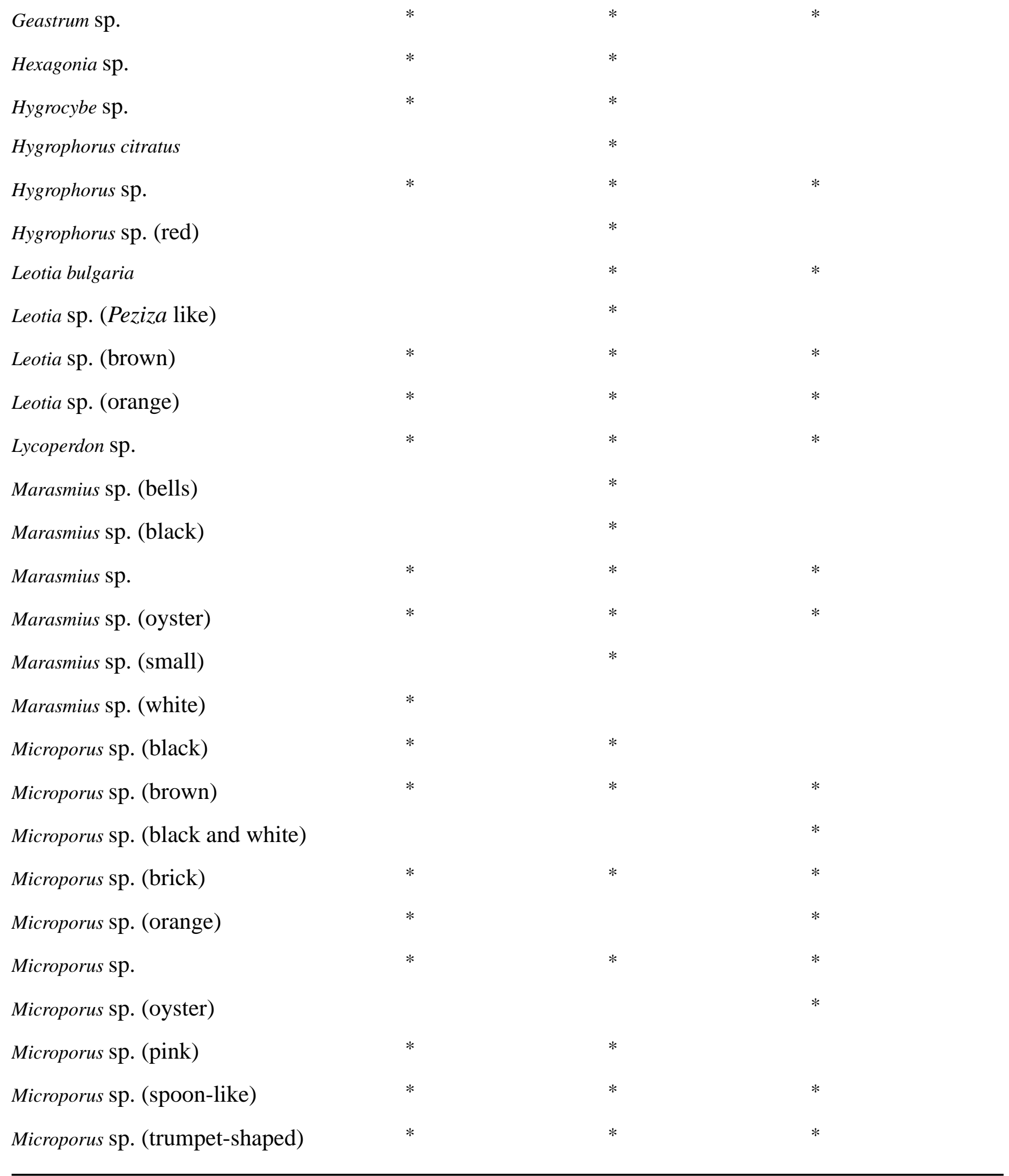




\begin{tabular}{|c|c|c|c|}
\hline Microporus sp. (velvet) & $*$ & $*$ & \\
\hline Microporus sp. (white) & $*$ & & \\
\hline Morchella sp. & $*$ & & $*$ \\
\hline Mycena sp. (brown) & $*$ & $*$ & \\
\hline Mycena sp. (leaf) & $*$ & $*$ & $*$ \\
\hline Mycena sp. (rufous) & $*$ & $*$ & $*$ \\
\hline Mycena sp. & $*$ & $*$ & $*$ \\
\hline Mycena sp. (white) & $*$ & & \\
\hline Myxomyceteae & * & $*$ & * \\
\hline Nidularia sp. (Cyathus like) & & $*$ & \\
\hline Otidia sp. (black) & & & $*$ \\
\hline Otidia sp. (Marasmius like) & $*$ & $*$ & $*$ \\
\hline Otidia sp. (orange) & & $*$ & \\
\hline Otidia sp. (Scutellinia like) & & $*$ & \\
\hline Peziza sp. (disk) & $*$ & $*$ & \\
\hline Phallus sp. (Mutinus like) & & $*$ & \\
\hline Phallus sp. (stalk) & & $*$ & \\
\hline Phellinus sp. & $*$ & $*$ & $*$ \\
\hline Physarium sp. & & $*$ & \\
\hline Physarium sp. (white) & & $*$ & \\
\hline Pleurotus sp. (orange) & & $*$ & \\
\hline Pleurotus sp. (oyster) & & & $*$ \\
\hline Pleurotus sp. & $*$ & $*$ & $*$ \\
\hline Polyporus sp. (black) & & & $*$ \\
\hline Polyporus sp. (brown) & $*$ & $*$ & $*$ \\
\hline Polyporus sp. (button) & $*$ & $*$ & $*$ \\
\hline Polyporus sp. (club) & & $*$ & \\
\hline
\end{tabular}




\begin{tabular}{|c|c|c|c|}
\hline Polyporus sp. (Coriolus like) & $*$ & $*$ & $*$ \\
\hline Polyporus sp. (grey) & $*$ & $*$ & $*$ \\
\hline Polyporus sp. (Hexagonia like) & $*$ & $*$ & $*$ \\
\hline Polyporus sp. (orange) & $*$ & $*$ & $*$ \\
\hline Polyporus sp. (oyster) & & $*$ & \\
\hline Polyporus sp. (pink) & $*$ & $*$ & \\
\hline Polyporus sp. (polyporous) & $*$ & $*$ & $*$ \\
\hline Polyporus sp. (resupinate) & $*$ & $*$ & $*$ \\
\hline Polyporus sp. (rusty) & $*$ & $*$ & $*$ \\
\hline Polyporus sp. (scars) & & $*$ & \\
\hline Polyporus sp. (spoon) & $*$ & & \\
\hline Polyporus sp. & $*$ & & \\
\hline Polyporus sp. (sulfur) & $*$ & $*$ & \\
\hline Polyporus sp. (trumpet) & $*$ & $*$ & $*$ \\
\hline Polyporus sp. (tubes) & $*$ & $*$ & $*$ \\
\hline Polyporus sp. (velvet) & & $*$ & $*$ \\
\hline Polyporus sp. (white) & $*$ & * & \\
\hline Rhizopogon sp. & $*$ & * & \\
\hline Russula sp. (brown) & & $*$ & \\
\hline Russula sp. (pink) & & $*$ & \\
\hline Russula sp. (purple) & & $*$ & \\
\hline Russula sp. (red) & & $*$ & \\
\hline Sarcocypha sp. (orange) & $*$ & $*$ & \\
\hline Sarcocypha sp. & $*$ & $*$ & $*$ \\
\hline Schizophylum sp. & $*$ & * & $*$ \\
\hline Tephrocybe sp. & & $*$ & \\
\hline Termitomyces sp. & $*$ & * & \\
\hline
\end{tabular}


Tremella sp. (jelly)

Tremella sp. (orange)

Tricholomataceae (Armillaria like)

Tricholomataceae (black)

Tricholomataceae (brown)

Tricholomataceae (campanulate)

Tricholomataceae (gills)

Tricholomataceae (grey)

Tricholomataceae (huge)

Tricholomataceae (large, edible)

Tricholomataceae

Tricholomataceae (mucilage and brown)

Tricholomataceae (orange)

Tricholomataceae (Oudemansiella like)

Tricholomataceae (oyster)

Tricholomataceae (pink)

Tricholomataceae (purple)

Tricholomataceae (red)

Tricholomataceae (ring)

Tricholomataceae (small, edible)

Tricholomataceae (silver)

Tricholomataceae (trumpet)

Tricholomataceae (white)

Xylaria sp.

Xylaria sp. (balls)

Xylaria sp. (carrot)

Xylaria sp. (club-shaped)

Xylaria sp. (long)

Xylaria sp. (monstrous)

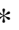

$*$

$*$

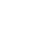




\begin{tabular}{|c|c|c|c|}
\hline Xylaria sp. (rod-like) & $*$ & $*$ & $*$ \\
\hline Xylaria sp. (short) & $*$ & $*$ & $*$ \\
\hline Xylaria sp. (thin) & $*$ & $*$ & $*$ \\
\hline
\end{tabular}

